Francis Leneghan

\title{
Translatio Imperii: The Old English Orosius and the Rise of Wessex
}

Abstract: This article argues that the Old English Orosius, a work traditionally viewed as a product of the educational reforms of King Alfred of Wessex (r. 871899), can be constructively read in relation to developments in Anglo-Saxon political thought in the early tenth as well as in the late ninth centuries. The earliest extant manuscript of the Orosius was probably copied at Winchester in the early tenth century by the same scribe responsible for the entries for the late ninth and early tenth century in MS A of the Anglo-Saxon Chronicle. This section of the Chronicle charts both the break-up of the Carolingian Empire and the conquests of Alfred and his successors, Edward the Elder and Æthelstan, over various kings and peoples of Britain. Treating the reports of Ohthere and Wulfstan contained in the geographical preface to the Orosius as an integral part of the text as it was read in the early tenth century, rather than as an extraneous interpolation, I suggest that this passage invites readers to consider the rapidly expanding West Saxon kingdom in relation to the great empires which preceded it. I then outline how the translator refashioned Orosius's 'universal history' into a work of imperial history which is more directly concerned with Rome's long and difficult rise than with its fall to the Goths in 410. I conclude that the Orosius might have encouraged early tenth-century Anglo-Saxon readers to interpret the recent rise of Wessex to overlordship in Britain as part of an ongoing process of translatio imperii, the transference or succession of empires, contingent on the Christian virtue of its rulers.

Francis Leneghan, St Cross College, Oxford

E-Mail: francis.leneghan@ell.ox.ac.uk

\section{The Old English Orosius and the Alfredian Canon}

The Old English Orosius (OEO), a free rendering of Orosius's Historiarum adversum paganos libri VII $(\mathrm{OH})$ (c. 417), survives in two principal manuscripts, the earliest of which, British Library Additional MS 47967 (the Lauderdale or Tollemache Manuscript), was copied by a single scribe probably working at Win- 
chester in the early tenth century. ${ }^{1}$ The date of the translation itself is unknown, though the use of early West Saxon dialect points to composition in the late ninth or early tenth century and, although William of Malmesbury's claim that King Alfred himself was the author has long been discredited on stylistic grounds, ${ }^{2}$ OEO has traditionally been regarded as a product of the educational reforms of the latter part of his reign, that is, the last decade of the ninth century.

Early scholarship tended to downplay the translator's capabilities as a Latinist: his work has been characterized as "full of confusions and misunderstandings" (Whitelock 1966: 92) and it has been claimed that so much of Orosius's text has been cut that $O E O$ is "little more than one-fifth of the length of its primary source” (Bately 1980a: xcvii). However, in a recent study Malcolm Godden argues that the translator skilfully adapted his sources by purposefully reorganizing, cutting and adding material and inserting his own comments, in order to produce "a lively and effective series of stories from ancient history, not a mere digest of Orosius" (2011a: 319). ${ }^{3}$ Moreover, Godden also notes that the extent of cutting involved in the act of translation has been greatly exaggerated: "The Old English version is in fact more than half as long as the Latin, and most of the omission is in the last three books; it omits little of substance in the historical narrative in the first four books, up to the fall of Carthage" (2011a: 319). Godden's identification of

1 Ker (1957: 164-166, n. 133) dates this manuscript s. $x^{1}$ and identifies the hand with the scribe responsible for fols. $16^{\mathrm{v}}-25^{\mathrm{v}}$ of the Parker Chronicle, which he argues was copied at Winchester (57-59, n. 39). Gneuss and Lapidge (2014: 227, n. 300) suggest the Lauderdale Orosius was copied “s. $\mathrm{x}^{1}$ or $\mathrm{x}^{2 / 4}$, Winchester?". The other major manuscript of $O E O$ is an eleventh-century copy, fols. 3-111 ${ }^{\mathrm{v}}$ of British Library MS Cotton Tiberius B i (the Cotton MS) (Ker 1957: 251-253, n. 191); for discussion of the position of the $O E O$ in this manuscript see Tyler (forthcoming). Fragments of $O E O$ survive in two further eleventh-century manuscripts: Bodleian Library MS Eng. Hist. e. 49 (30481) (Ker: 384, n. 323) and Vatican Library MS Reg. Lat. 497 (Ker: 459, n. 391). The standard edition is Bately (1980a), from which all quotations are taken. All translations are my own unless otherwise stated. For a modern English translation of $O E O$, see Bosworth (1859); Malcolm Godden is currently preparing a translation for the Dumbarton Oaks Medieval Library. For an overview of scholarship up to 1997, see Waite (2000: 38-42, 281-320). The most detailed discussion remains Potter (1953). For a recent overview of authorship, date, language, sources and style, see Bately (2014). The Latin text of $\mathrm{OH}$ is cited from Zangemeister (1889); modern English translation, when indicated, is from Fear (2010).

2 William claims that, in addition to $\mathrm{OH}$, Alfred translated Gregory's Cura Pastoralis, Boethius's De Consolatione Philosophiae, Bede's Historia Ecclesiastica, a handbook (perhaps Augustine's Soliloquia) and part of the psalter, Gesta Regum Anglorum (henceforth GRA) II. 123 (Mynors et al. 1998: 192-194). But see Bately (1970); Liggins (1970). Lapidge (2003: 33-34, 41) argues that Asser, who makes use of $\mathrm{OH}$ in his Vita Alfredi, dictated the translation to an English scribe. However, see now Russell (2011).

3 For a useful comparison of the Latin and Old English texts, see Khalaf (2013: 208-219). 
the main source as a heavily glossed Frankish copy of $O H$ (2011a) means that $O E O$ can be viewed as a product of the ongoing translatio studii, transfer of knowledge or learning, ${ }^{4}$ from Carolingian Francia to Anglo-Saxon England, which took place in the ninth and tenth centuries, bringing with it new ideas about religion, philosophy, history, kingship and empire. ${ }^{5}$

However, the familiar narrative of 'Alfredian prose', according to which Alfred and his circle of scholars, in a burst of activity in the last decade or so of the ninth century, themselves produced the Old English Dialogues, Pastoral Care, Boethius, Soliloquies and Prose Psalms as well as OEO, has recently been called into question in a series of articles by Godden (2007, 2009, 2011a, 2011b, 2011c, 2013). In reply, Janet Bately (2009) has defended, mostly on lexical grounds, the traditional view that Alfred was probably the author of the Pastoral Care, Boethius, Soliloquies and Prose Psalms. But the confidence with which scholars once assigned all of these texts, both those thought to be the king's own works and others such as $O E O$ thought to have been commissioned by him, to Alfred's reign has now been replaced by a cautious uncertainty. For example, the editors of the recent Companion to Alfred the Great, borrowing the terminology of Michel Foucault, suggest: "We may find it useful to think of 'Alfred' as an author function more than a biographical description" (Discenza and Szarmach 2014: 4). ${ }^{6}$ How does this re-evaluation of Alfred's status as an author affect our understanding of the context and origins of the $O E O$ ?

The relationship between $O E O$ and what Bately terms the 'Alfredian canon' depends largely on the unusual spelling of the names of two Gothic kings which it shares with the Old English prose Boethius (commonly referred to as the B-text). ${ }^{7}$ If we accept the claims of the prose and verse prefaces to the Boethius that Alfred was the author of at least the B-text, and accept that this text is itself indebted to $O E O$ here rather than the other way round, then we may establish a terminus ad quem for the composition of $O E O$ in 899, the year of Alfred's death. However, both Frantzen $(2003)$ and Godden $(2007,2009,2013)$ have argued that the prefaces to

4 For discussion of the concept, see Curtius (1953: 29); Verger (1997).

5 See Wallace-Hadrill (1975); Story (2003); and Rollason, Leyser and Williams (2010). For AngloSaxon influence on Charlemagne's renovatio, see Levison (1946).

6 See also Pratt (2007b). Arguments concerning the 'authorship issue' are helpfully summarized in an appendix to Discenza and Szarmach (2014: 397-415).

7 See Whitelock (1966: 73-74, 89-94); and Bately (1980a: xcii-xciii). Compare OEO: Rædgota and Alrica (Bately 1980a: 155, 1. 23 and 26-27, 156, 1. 13 and 19) with Old English Boethius (B-text): Rædgota and Eallerica (Godden and Irvine 2009, I: 243, 1. 1-3). By comparison, the prosimetrical Boethius (C-text) has Rædgod/Rædgot and Aleric (Godden and Irvine 2009, I: 384, 1. 7 and 19). For discussion of this and other possible connections between $O E O$ and other 'Alfredian' works, see Bately (2014: 342). 
the Boethius should be regarded more as authenticating devices than as true statements of authorship. If the Boethian prefaces' claims of royal authorship are fictional, then the Boethius B-text might have been composed as late as around 950, the date of the earliest extant manuscript of the prosimetrical C-text, which itself is probably derived from the B-text (Godden and Irvine 2009, I: 145-146). ${ }^{8}$ As Godden has subsequently argued, this extension of the dates for the composition of the B-text of the Boethius into the mid-tenth century pushes back the terminus ad quem for $O E O$ to around 930, the approximate date of the Lauderdale Manuscript (2011a: 9). ${ }^{9}$

\section{The Purpose and Main Themes of the Old English Orosius}

The contentious issue of the OEO's date is, of course, of great significance for the study of its underlying purpose and main themes. $\mathrm{OH}$ itself is a classic example of the popular genre of 'universal history', beginning with the Creation and Fall before charting the history of the four great empires of the world, namely Babylon (and Medes-Persia), Macedon, Carthage and Rome, down to the present, within an eschatological framework (Allen 2003). Though sometimes dismissed by modern historians as "superficial” (Mayr-Harting 2001: 55), $\mathrm{OH}$ was immensely popular in the Middle Ages (Mortensen 1999-2000) and there is evidence for its circulation in Anglo-Saxon England from an early period (Lapidge 2006: 183 and 221). Working from the position that the Old English version was composed before 899, various scholars have suggested that Alfred selected $\mathrm{OH}$ for translation in order to provide his subjects with a Christian account of world history to supplement the national histories of the Old English Bede and Anglo-Saxon Chronicle (ASC). ${ }^{10}$ Janet Bately, the text's modern editor, argued that the main purpose of the translation was to foreground the impact of Christ's birth on human history (1980a: xciv), but as Omar Khalaf has recently commented, "the omission of any reference to the birth of Christ in Book IV, ch. 1" (2013: 200) makes this seem improbable, and a number of recent studies have sought to connect $O E O$ with the

8 See Godden and Irvine (2009, I: 150).

9 In her most recent analysis, Bately comments that $O E O$ "could well have been [composed] during Alfred's lifetime"; however, acknowledging Godden's arguments for widening the dating range, she also accepts that "a very slightly later date [than 899] cannot be ruled out” (2014: 342). 10 See, for example, Bately (1980b: 6); Kretzschmar (1987: 143); Irvine (2001: 139). 
specific ethnographic, religious, military and political concerns of Alfred's reign. ${ }^{11}$ In an important study, William Kretzschmar Jr. (1987) demonstrated that the translator rarely cuts and often embellishes passages from $\mathrm{OH}$ treating the transmission of anweald/onweald 'power', 'kingdom', 'empire', ${ }^{12}$ suggesting that he was especially interested in the idea of translatio imperii, the succession or transference of empires. ${ }^{13}$ As Godden (2002: 61) has argued, it is difficult to see why an English translator of $\mathrm{OH}$ would display such an interest in translatio imperii in the last decade of the ninth century:

It is of course possible to argue that for the Alfredian world the Roman empire was still flourishing, by virtue either of the continuing presence of the eastern empire in Byzantium or the ninth-century revival of the western empire under the Carolingians (though the last decade of the ninth century is a singularly bad period for that claim, since the imperial throne had fallen into the hands of a Lombard duke). ${ }^{14}$

However, the possibility of early tenth century composition subsequently raised by Godden opens up new ways of reading OEO. It appears that during this period, immediately following the collapse of the Carolingian Empire, West Saxon rulers began to conceive of their rule over the various peoples of the island of Britain in imperial terms. Moreover, Michael Wood (1983: 266-267; 2007; 2010) and Veronica Ortenberg (2010: 222-226) have argued that, in the eyes of some commentators, a translatio imperii had taken place from Francia to Wessex. ${ }^{15}$ Wood stresses that Æthelstan "was the most powerful ruler Britain had seen since the Romans” and terms him “an English Charlemagne” (1983: 250), while Ortenberg (2010: 236) has commented:

Not only was Æthelstan actually perceived in the former Carolingian empire as the only existing ruler in the Carolingian style at that time, a new Charlemagne, but he was felt to be, and he saw himself, as a member of the Carolingian kin, somebody who had political interests on the Continent and in preserving that kin in power.

11 Harris (2001); Hurley (2013); Khalaf (2013); Pezzarossa (2013). Pratt restricts his study of Alfredian 'political thought' to those works traditionally ascribed to the king himself (i.e. Pastoral Care, Boethius, Soliloquies and Prose Psalms) and therefore only touches briefly on OEO (2007a: 117-118).

12 See below (pp. 678-679) for discussion of this term.

13 For discussion of this theme, see Goez (1958); Thomas (1997). As Curtius (1953: 28) notes, in Christian tradition the concept of translatio imperii has its roots in Ecclesiasticus 10.8: "Because of unrighteous dealings, injuries, and riches got by deceit, the kingdom is transferred from one people to another".

14 See below (pp. 667-669) for discussion of the break-up of the Carolingian empire.

15 See below (pp. 672-673). 
This article does not attempt to resolve the contentious issue of the date of $O E O$ 's composition. Rather it seeks to explore how $O E O$, in particular its interest in the theme of translatio imperii, might have been read against these developments in Anglo-Saxon political thought in the late ninth and early tenth centuries, taking into account the possibility of its reception and use in West Saxon court circles in the immediately post-Alfredian period.

The manuscript evidence indicates that $O E O$ was read, copied and perhaps revised in the early tenth century. Neil Ker (1957: 57-59, n. 39) identified the scribe of the Lauderdale Orosius with the hand responsible for fols. $16^{\mathrm{v}}-25^{\mathrm{v}}$ of the Parker (or Winchester) Chronicle (fols. $1^{\mathrm{v}}-32^{\mathrm{v}}$ of Cambridge Corpus Christi MS 173), containing annals 891 (second part)-920, ${ }^{16}$ and the Latin (and perhaps Old English) text of the Junius Psalter contained in fols. 10-149 of British Library MS Junius 27 (Ker 1957: 408-409, n. 335). The likely provenance of this group of texts at Winchester c. 920-930 suggests that the copying of the Lauderdale Orosius can be connected to the interests of the West Saxon royal house in this period.

As preliminaries to my discussion of imperial themes in the $O E O$ itself I present a brief outline of Orosius's vision of history, a survey of the ASC's presentation of relations between Wessex, Carolingian Francia and Rome in the ninth and tenth centuries and a discussion of the emergence of West Saxon imperialism under Alfred and his immediate successors.

\section{The Four Empires and the Persistence of Rome}

The Church Fathers responded in a variety of ways to accusations that the fall of the Roman Empire was a direct result of its recent acceptance of Christianity.

16 All ASC references are to MS A (Bately 1986) unless otherwise stated. Annals up to 891 (first part) are copied by a single late ninth- or early tenth-century hand. Ker (1957: 58-59) regards the continuation from 891 (second part) -920 as the work of a single scribe. Bately (1986: xxv-xxxiv) surveys arguments for multiple scribes copying this section of the Parker Chronicle, and suggests that the scribe responsible for the Lauderdale Orosius, whom she calls "2a", copied only fols. $16^{\mathrm{v}}-17^{\mathrm{v}}$ of the Parker Chronicle, i.e. ASC 891 (second part)-893 (first part) (xxviii, xxxii). Parkes (1976) also favours multiple scribes, arguing that "scribe 2" copied ASC 891 (second part)-911, and "scribe 3" copied ASC 911-920. Dumville (1992a: 67-68), however, supports Ker's belief that fols. $16^{\mathrm{V}}-25^{\mathrm{r}}$ are indeed the work of a single scribe but argues that he wrote these annals "on two quite separate occasions" c. 915-930. In Dumville's view, this scribe first copied ASC 891 (second part)-911, then the Lauderdale Orosius, then ASC 912-920. After the continuation up to 920, a mid tenth-century hand wrote the annals up to 955. For discussion of the royal inspiration behind the ASC and its continuations, see Brooks (2010). For discussion of the ASC's origins and various stages of compilation, see Bately (1985) and Irvine (2014b). 
Jerome, for example, in his Commentariorum in Danielem Libri III (c. 407), emphasized that the fate of all empires, including Rome, is subject to Providence:

Ipse mutat tempora et aetates, transfert regna atque constituit [Dan. II. 21]. Non ergo miremur siquando cernimus et regibus reges et regnis regna succedere quae Dei gubernantur et mutantur et finiuntur arbitrio. (Glorie 1964: 787)

““[And] he changeth times and ages: taketh away kingdoms, and establisheth them” [Dan. II. 21]. Let us not marvel, therefore, if at any time we see kings and empires succeed one another, for it is by the will of God that they are governed, changed and ended'.

In his eschatological reading of Nebuchadnezzar's dream (Dan. II:31-40), Jerome interprets the statue of gold, silver, bronze and iron as prefiguring the rise and fall of the four great empires of the world: the gold head represents the first empire, Babylon; the chest and arms of silver the empires of Medes and Persia; the belly and thighs of bronze the empire of Macedon; and the feet of iron Rome, the fourth and final empire. Jerome predicts that this process of translatio imperii will end with the Second Coming:

[I]n fine autem horum omnium regnorum [...] et, contritis omnibus regnis: Factus est mons magnus, et implevit universam terram [Dan. II. 35]. (Glorie 1964: 795)

'At the end of all these empires [...] and after all the empires had been broken, He became a great mountain and filled the whole earth [Dan. II. 35]'. ${ }^{17}$

Written in the immediate aftermath of the sack of Rome by the Goths in 410, Augustine's De Civitate Dei contra Paganos (413-427) built on Jerome's exegesis of Daniel II in contrasting the temporal fate of Rome, typifying the Earthly City, with the eternal glory of the Heavenly City, the kingdom of God. Maintaining that Rome's downfall was brought about by the immorality of its citizens rather than by its recent abandonment of the old gods, Augustine railed against those who blamed Christ for disasters which, he argued, were brought upon them by their own sins (I.3). But lacking time and space to provide the evidence to support this view (IV.3), Augustine commissioned Orosius to catalogue the litany of disasters which had befallen Rome and other kingdoms before the coming of Christ.

In arguing that the fall of pagan kingdoms was a result of the sins of their rulers and continually insisting how much worse times were before Christ, Oro-

17 For discussion of the four empires in relation to the Augustinian scheme of the six ages of the world, see Curtius (1953: 28). 
sius follows his master, Augustine. ${ }^{18}$ However, where Orosius departs from his predecessors is in his remarkably positive interpretation of the events of 410 and in his optimistic vision of the future of the Roman Empire. While for Jerome and Augustine the fall of Rome was necessary for the establishment of the dominion of Christ, for Orosius the cycle of the four empires reaches its fulfilment, rather than its denouement, with the rise of Rome, which in his view had survived the sack of 410 due to God's intervention in history and would continue to reign until the end of the world..$^{19}$ Orosius alters Jerome's four-empires scheme by collapsing the first two empires, Babylon and Medes-Persia, into a single era, and by promoting Carthage into the gap between Macedon and Rome, thereby placing more emphasis on Rome's great struggle against Carthage and its eventual emergence as the last great empire. ${ }^{20}$ In this vision of world history, God showed His favour to the Romans not only by allowing them to be conquered by a relatively clement Christian people, the Goths, but also by sending His Son to redeem mankind during the Pax Augusta, marking the Romans out as rerum dominos 'masters of the World' (cf. Virgil, Aeneid, I, 1. 282) and bringing Rome to rerum apiciem 'the apogee of power' (VI.22.7-8; Fear 2010: 316). In emphasizing Christ's Roman citizenship, Orosius allows for the extension of Roman imperium beyond 410 until the Second Coming and the establishment of the eternal city. This innovation made $\mathrm{OH}$ especially useful both to medieval rulers, who sometimes styled themselves as latter-day Roman emperors, and to their ecclesiastical supporters, who promoted the idea of the renewal of the Roman Empire as an imperium christianum. ${ }^{21}$

\section{The Anglo-Saxon Chronicle on Wessex, the Carolingians and Rome in the Ninth Century}

Sarah Foot (2005) has recently argued that the items chosen by an annalist for inclusion (as well as those omitted) provide important clues to the ideologies underlying a chronicle's composition. ${ }^{22}$ The ASC, the first major European vernacular chronicle, not only constitutes our main contemporary source for AngloSaxon history, but also offers valuable information as to how ruling English

18 See Fear (2010: 7-13).

19 See Van Nuffelen (2012: 52-53).

20 See Fear (2010: 19); Van Nuffelen (2012: 48-49).

21 For discussion of the renewal of the Roman Empire in the medieval West, see Ladner (1983: 457-485, 544-547). On the reception of Orosius in the early Middle Ages, see Hillgarth (1992).

22 See also Irvine (2014b: 345-349). 
dynasties, especially Wessex, viewed their relationships with both their continental counterparts and Rome. Early annals record how the Romans - like the AngloSaxons after them - first Bretenlond gesohte 'sought out Britain', striving against the Weallas 'Welsh' for dominion over the whole island (ASC 60BC, 46AD) (Bately 1986: 2-4). ${ }^{23}$ While the account of the Roman military withdrawal and the Gothic sack of Rome in ASC 409 marks the end of Roman military rule in Britain (Her Gotan abræcan Romeburh, 7 næfre syððan Romane ne rixodan on Brytene 'Here the Goths sacked Rome, and since then the Romans have never ruled in Britain') (Bately 1986: 15), ${ }^{24}$ the idea of Rome, as both the centre of Western Christianity and as a model of imperial rule, continued to play an important role in the minds of educated Anglo-Saxons long after the withdrawal of the legions (Howe 2001; Scharer 2010: 164). ${ }^{25}$ This is reflected in the frequent references to subsequent contact with Rome in the ASC: for example, annals for the sixth and seventh centuries emphasize the impact of Roman missionaries in bringing about the conversion of first the Britons and then the Anglo-Saxons themselves, while pilgrimages made by English bishops and kings to Rome are recorded in numerous annals from the seventh to the ninth century. ${ }^{26}$ Of most significance to this discussion, however, is the special emphasis ASC gives to Wessex's privileged relationship with Rome. ${ }^{27}$ As Susan Irvine (2003a) has shown, this is most evident in annals for the second half of the ninth century, which were probably composed by a late ninth- or early tenth-century chronicler actively promoting the interests

23 Compare the 'West-Saxon Genealogical Preface' to the ASC, copied by the same hand responsible for the entries up to 891: Pa feng Ęlfred hiera bropur to rice, 7 pa was agan his ielde. xxiii. wintra 7 ccc. $7 . x c v i$. wintra bæs pe his cyn ærest Westseaxna lond on Wealum geeodon 'Then their brother Alfred succeeded to the kingdom, and he was then 23 years old; and it was 396 years since his ancestors had first conquered the West Saxons' land from the Britons' (Bately 1986: 2). See further Dumville (1986); Irvine (2014b: 353-354). On the presentation of the West Saxons as heirs to Rome in the ASC, see Karkov (2004: 18-20). Through a close comparison of the use of historical sources in OEO and the early annals of ASC, Bately (1979: 191) concludes that the evidence is "against any close connection between the composition of the two works". But see below (pp. 669-671, 678-697) for a discussion of the treatment of empires in the late ninth- and early tenth-century ASC annals and OEO; on paleographical connections between ASC 891 (second part)-920 (Parker Chronicle) and the earliest extant version of OEO, the Lauderdale Orosius, see above (p. 661) and below (pp. 695-696).

24 For the treatment of the fall of Rome in Bede, ASC, OEO and other sources, see Godden (2002). 25 For the argument that the Anglo-Saxons were less interested in Roman history than their continental contemporaries, see $\mathrm{Coz}$ (2010).

26 ASC 167 (baptism of Lucius, king of the Britons, by Pope Eleutherius); ASC 601, 625, 626, 627, 632, 634 (evangelism of Augustine, Paulinus and Birinus).

27 See further Pengelly (2010). 
of the West Saxon dynasty. ${ }^{28}$ For example, while a letter from Pope Leo IV to Æthelwulf describing Alfred's visit to Rome states that the pontiff honoured the young prince with the standard gifts of a consul's sword and belt (Whitelock 1979: 880, n. 219), ASC 853 transforms this event into a royal anointing, with echoes of Old Testament and Carolingian custom, whereby the pope consecrated (gehalgode) Alfred as king (Bately 1986: 45). ${ }^{29}$ The anointing of Carolingian rulers as an expression of papal approval had begun as early as Pepin's accession in 751 (Nelson 1977). ${ }^{30}$ But the anointing and coronation of Charlemagne by Pope Leo III in Rome on Christmas Day 800 signalled the rebirth of the imperium romanum as an imperium christianum. ${ }^{31}$ ASC 853's presentation of Alfred as God's anointed, chosen by the pope from among his brothers to rule, invests West Saxon kingship with something of the mystique of the Carolingian emperors and encourages the Angelcynn to think of themselves as, if not necessarily a "new Israel", ${ }^{32}$ then certainly as being “among God's chosen” (Molyneaux 2014: 721). ${ }^{33}$

This Roman-Carolingian-West Saxon nexus is again foregrounded in the long ASC entry for 855 (=856), which describes Æthelwulf's state visit to Rome and subsequent marriage to Judith, daughter of Charles the Bald, himself a grandson of the emperor Charlemagne (Bately 1986: 45). Royal marriages between AngloSaxon and Frankish dynasties had taken place since the days of Æthelberht and Bertha, but Sarah Foot has suggested that the wedding of Æthelwulf and Judith inaugurated "a new trend in West Saxon royal thinking” (2010: 245), whereby alliances with continental, rather than insular, dynasties were increasingly sought. Æthelwulf and Charles shared a common enemy in the Vikings and both rulers were confronted with a disputed succession, so the pragmatism of a political alliance may have been the main driving force behind this marriage

28 Parkes (1976) argues that the 'common stock' of the ASC up to the first part of the annal for 891 was copied by a single scribe in the late ninth century. However, Dumville (1992a) proposes that the scribe who copied entries up to 891 was in fact writing in the early tenth century. For a recent review of the arguments, see Irvine (2014b: 350-352).

29 See Nelson (1967); Keynes (1997); Irvine (2003a: 67); Irvine (2003b: 187-188). ASC 885 and 887 record the freeing of the English school in Rome by Pope Marinus at Alfred's request and the exchange of gifts, relics and alms between the king and the papacy (Bately 1986: 52-53).

30 The practice is first recorded in Anglo-Saxon England with the anointing of Offa of Mercia's son, Ecgfrith (ASC 785 (=787)).

31 See Fichtenau (1968); and Ullmann (1969: 135-166).

32 For the view that the Anglo-Saxons (following the Franks) had an unusually developed sense of their own chosenness, see Howe (1989); and Wormald (1994).

33 On the promotion of the term angelcynn in the Alfredian period, see Foot (1996); Wormald (1994); and Stodnick (2006). 
(Enright 1979; Stafford 1980; Keynes and Lapidge 1983: 234-235, n. 26; Nelson 1997: 141-158; Story 2003: 224-243). ${ }^{34}$ But in terms of prestige, Wessex certainly stood to gain considerably more from an alliance with the powerful king of the West Franks. Despite the fact that Charles the Bald was not himself crowned emperor until 875, Æthelwulf had nonetheless succeeded where Offa of Mercia before him had failed, in marrying into the royal house of Charlemagne (Story 2003: 135-142). The respect which Æthelwulf's new Carolingian bride commanded in Wessex is hinted at by Asser's observation that the king took the unusual step of having Judith sit beside him on the throne, contra perversam illius gentis consuetudinem 'though this was contrary to the (wrongful) custom of that people' (Stevenson 1959: 11; Keynes and Lapidge 1983: 73). ${ }^{35}$ Indeed, so prized was Carolingian blood in Wessex that after Æthelwulf's death in 858 his eldest son, Æthelbald, also married Judith, much to the disgust of Asser. Neither marriage produced an heir, but the West Saxon and Carolingian dynasties became increasingly intertwined in the latter part of the ninth century, with Alfred arranging for his daughter, Ælfthryth, to be married to Baldwin II, Judith's son from her third marriage to Baldwin I of Flanders. ${ }^{36}$

The growing confidence of the West Saxon dynasty in the second half of the ninth century is reflected in the cult of royal genealogy. Æthelwulf's impressive list of ancestors, stretching back to Adam and Christ via the line of Sceaf, a legendary Danish king said to have been born in Noah's ark, is included in the same 855 annal which describes his visit to Rome and marriage to Judith (Bately 1986: 45-46). ${ }^{37}$ As Barbara Yorke (2010: 148) notes, royal genealogies are usually included in the annal recording a king's accession; the provision of Æthelwulf's pedigree here, in the year of his death, exactly a century after the annal containing Offa's much shorter list of ancestors, may reflect the chronicler's desire to highlight the supremacy of Wessex over Mercia. Moreover, Daniel Anlezark has argued that the genealogist's transformation of Sceaf into the ark-born son of Noah effectively "privileged the West Saxons among all northern peoples" (2002:

34 The marriage may have provoked the revolt of Æthelwulf's son, Æthelbald. The ASC glosses over the matter, but details are provided by Asser (De Rebus Gestis Alfredi XI-XIII) (Stevenson 1959: 9-11; Keynes and Lapidge 1983: 70). On Charles's dynastic problems, see Nelson (1991: 82); and McKitterick (1983: 169-199, esp. 194-195).

35 ASC 855 simply states: him pa Carl Francna cyning his dohtor geaf him to cuene 'Charles, King of the Franks, gave him his daughter as queen' (Bately 1986: 45).

36 See Nelson (2003: 297). For further discussion of contacts between Alfred and the Carolingians, see Wallace-Hadrill (1975); and Irvine (2003b).

37 For the argument that the inclusion of Danish kings in this genealogy reflects the integration of English and Danish ethnicities following Alfred's victories over the micel here, see, for example, Murray (1981: 105). 
45). ${ }^{38}$ In their genealogies as in their royal marriages, by the end of the ninth century the West Saxons were increasingly coming to think of themselves as equals, if not superiors, to their illustrious continental cousins, the Carolingians.

From the late eighth to the late ninth centuries, the Carolingians ruled a vast empire incorporating most of the various subkingdoms of continental northwestern Europe. Writing c. 883 during the reign of Charles the Fat (881-888), Notker the Stammerer begins his life of Charlemagne with an account of a translatio imperii from Rome to Francia based on Jerome's interpretation of Nebuchadnezzar's dream, in which the Carolingian Empire stands in the position of the fifth (and by implication last) world empire: ${ }^{39}$

Gesta Karoli I.1: Omnipotens rerum dispositor ordinatorque regnorum et temporum, cum illius admirandę statuę pedes ferreos vel testaceos comminuisset in Romanis, alterius non minus admirabilis statuę caput aureum per illustrem Karolum erexit in Francis. (Haefele 1959: 1)

'He who ordains the fate of kingdoms and the march of the centuries, the all-powerful Disposer of events, having destroyed one extraordinary image, that of the Romans, which had, it was true, feet of iron, or even feet of clay, then raised up, among the Franks, the golden head of a second image, equally remarkable, in the person of the illustrious Charlemagne'. (Thorpe 1969: 94)

However, the death of Charles the Fat without legitimate heir in 888 saw the break-up of the Carolingian Empire; the idea of a central European, Christian imperium was not to be revived until the coronation of Otto I in $962 .{ }^{40}$ The Chronicle of Regino of Prüm, completed at the former imperial city of Trier around 908, charts the rise and fall of the Carolingian dynasty and its empire in terms of a Boethian wheel of fortune, reaching its peak with Charlemagne before dissolving into separate parts after Charles the Fat's death (MacLean 2009: 182-183, 198200). ${ }^{41}$ Like Orosius, Regino wrote his history to admonish the rulers of his own day and to warn them of the dangers of internal discord. In his view, the empire's

38 See also Magoun (1951). Elizabeth Tyler has recently suggested that this genealogy, with its list of royal Scandinavian ancestors, sets Wessex apart from continental dynasties such as the Carolingians, who claimed descent from Troy, thereby expressing "both their place within, and yet their apartness from, Europe” (2013:1).

39 See Nelson (1988: 234).

40 On the various claims to the imperial title made by Charles's illegitimate son, Arnulf, and two kings of Italy, Louis the Blind (emperor from 901-905) and Berengar (915-924), both of whom were descended from Charlemagne through the maternal line, see Nelson (1988: 242-251).

41 See further Airlie (2006: 129-130). 
collapse after Charles the Fat's death was God's righteous punishment for the prevalence of folly and sin among the royal kin, specifically the immoderate desire for power on the part of the various Frankish sub-kings and the general sterility of the royal blood. ${ }^{42}$

The crises engulfing the Carolingian house in this period did not go unnoticed in Wessex: ASC 885 (=884) records the deaths of both Carloman (in a hunting accident) and his brother Louis, while emphasizing their close ties with the West Saxon dynasty: Carl wæs Karles sunu pe Epelwulf Westseaxna cyning his dohtor hæfde him to cuene 'Carloman was Charles [the Bald's] son, whose daughter King Æthelwulf of the West Saxons had as his queen’ (Bately 1986: 52). Similarly, ASC 887 (=888) describes the death of Charles the Fat and the subsequent division of the kingdom alongside an account of the unchecked progress of the Vikings in Francia: ${ }^{43}$

[887] Her for se here up purh pa brycge æt Paris $\urcorner$ pa up andlang Sigene op Mæterne op Cariei, $\urcorner$ pa sæton para 7 innan Ionan tu winter on pam twam stedum. 7 by ilcan geare forpferde Karl Francna cyning, 7 Earnulf his bropur sunu hine .vi. wicum ær he forbferde berędde æt pam rice, $\urcorner$ pa wearb pæt rice todęled on .v. ᄀ. v. kyningas to gehalgode. [...] $\neg$ pæt heoldun mid micelre unsibbe 7 tu folcgefeoht gefuhton 7 pæt lond oft 7 gelome forhergodon, 7 æhw węper operne oftrędlice ut dræfde. 7 by ilcan geare pe se here for forb up ofer ba brycge æt Paris [...]. (Bately 1986: 53).

'[887] Here the army went up through the bridge at Paris, and then up along the Seine as far as the Marne, up to Chézy, and then settled there and on the Yonne, two winters in those places. And the same year Charles, king of the Franks, [i.e. Charles the Fat] passed away, and Arnulf, his brother's son, dispossessed him of the kingdom six weeks before he passed away. And then the kingdom was divided into five, and five kings were consecrated to it; [...] and they held that in great discord, and fought two national fights, and over and again ravaged that land, and each regularly drove out the other. And the same year when the raiding-army went up beyond the bridge at Paris [...]'. (Emphasis added)

In painting such a negative portrait of the conduct of the five rival claimants to the Frankish throne, the ASC, like Regino, implies that the remnants of the Carolingian royal family are themselves to blame for this crisis. However, the English chronicler differs from Regino in the fact that, from his near-contemporary perspective on the events of 888 , he appears to still believe in the persistence

42 Airlie (2006: 131) notes that Regino attributes the failure of the Carolingian line mostly to the sterility of Frankish queens; in the entry for 886, detailing the divorce of Lothar II, Regino quotes Pope Nicholas I's assertion that even such a seemingly neutral failing can be viewed as a manifestation of sin.

43 On connections between the break-up of the Carolingian Empire and the progress of the Vikings, see MacLean (2003: 17). 
of Carolingian imperial authority. As Janet Nelson comments: "Only with hindsight, writing at least a decade later, did Regino present 888 as a total and definitive splitting of the Empire" (2003: 301). ${ }^{44}$ Arnulf's wars against the Danes are recorded in ASC 891, but after this point ASC makes no mention of the remaining descendants of the Carolingian dynasty. Instead, ASC entries for the 890s-930s focus almost exclusively on Wessex-led resistance to the Danes and the subsequent conquest of Britain by Alfred's successors, Edward and Æthelstan. It was not until the first few decades of the tenth century, with the Carolingians and their empire now firmly consigned to the past, that the royal house of Wessex began to develop an imperial identity of its own.

\section{The Rise of Wessex in the Late Ninth and Early Tenth Centuries}

Although the imperial ambitions of the West Saxon kings in the late ninth and early tenth centuries may have gained impetus from recent events in Francia, the concept of an insular overlord built on earlier Anglo-Saxon custom. Hence Bede's list of seven reges who held imperium over Southumbria (Historia Ecclesiastica, II.5) ${ }^{45}$ was updated in ASC 827 (=829) to include Ecgbert of Wessex as the eighth Bretwalda 'British ruler' or Brytenwalda 'wide ruler' ${ }^{46}$ following his conquest of Mercia and all the land south of the Humber. In the Chronicle's account, Ecgbert also received the submission of Northumbria and North-Wales (ASC 827 [=829], 828 [=830]), while his successor, Æthelwulf, assisted the Mercian king Burhred in subduing North Wales (ASC 853). West Saxon expansionism continued under Alfred, who, according to the ASC, won the loyalty of the men of Somerset, Wiltshire and Hampshire (ASC 878) and all the Angelcynn not under Danish control (ASC 886 [=885], 900 [=899]), as well as receiving support against the Vikings from sum dæl pæs Norð Weal cynnes 'some part of the Northern Welsh people' (ASC 894 [=893]). ${ }^{47}$ The steady growth of the West Saxon realm in the late

44 See also Keynes and Lapidge (1983: 98).

45 See John (1966); Higham (1995); Wormald (1983); Fanning (1991); and Dumville (1997). For later developments in Anglo-Saxon and Anglo-Norman imperial kingship, see Nelson (1988: 239-242).

46 MS A has Bretwalda but all other MSS have Brytenwalda. See Bately (1986: cxvii, 42).

47 Asser (De Rebus Gestis Alfredi LXIII) records the submission of the southern Welsh kings to Alfred's imperio 'royal overlordship' (Stevenson 1959: 66; Keynes and Lapidge 1983: 96); see further Molyneaux (2011: 71-72). 
ninth century is reflected by the increasingly frequent use of titles such as rex saxonum and rex anglo-saxonum on coins and charters issued by Alfred..$^{48}$ The Welshman Asser dedicated his De Rebus Gestis Elfredi to Alfred, omnium Brittanniae insulae Christianorum rectori 'ruler of all the Christians of the island of Britain' (Stevenson 1959: 1; Keynes and Lapidge 1983: 67), ${ }^{49}$ but it was not until the early tenth century, with the more large-scale conquests of Edward and Æthelstan, that West Saxon kings, like the Carolingians before them, could seriously begin to consider themselves as kings of kings and rulers of peoples..$^{50}$ This new perception of the kings of Wessex as imperial overlords of the island continued throughout the tenth century, culminating in the 'rowing' of Edgar by all the kings of Britain on the River Dee in $973 .^{51}$

The ASC's record of how Edward became not only 'King of the Anglo-Saxons', ${ }^{52}$ as his father had been, but also overlord of much of Britain, closely echoes continental accounts of Carolingian empire-building. For example, Einhard states that Charlemagne, inheriting an already powerful and far-flung kingdom from his father, ita nobiliter ampliavit, ut poene duplum illi adiecerit 'increased it to such an extent that he almost doubled it' (Vita Karoli XV; Holder-Egger 1911: 17), winning the friendship of quibusdam regibus ac gentibus 'several kings and peoples' (Vita Karoli XVI; Holder-Egger 1911: 19). ${ }^{53}$ Similarly, ASC entries for 918 (=914) and 921 (=917) record the submission of Mercia, East Anglia, Essex and Northumbria to Edward, as well as the Norse Jarls Thurcytel and Thurferth and the raiding-armies in Northumbria, East Anglia and Cambridge; ASC 922 (=918) claims the submission of the kings of Wales, eall Norbweallcyn 'all the people of North-Wales' and all the inhabitants of Mercia, ægper ge denisc ge englisc 'both Danish and English' (Bately 1986: 68-69); and ASC 924 (=920) states that the rulers of the Scots, the Danish kingdom of York, Northumbria and the Strathclyde Welsh hine geces $p a$ to fæder 7 to hlaforde 'chose him as father and lord' (Bately 1986: 69). Although in reality the political and constitutional significance of these claims may have been

48 For example, a charter from Alfred to Æthelhelm (S 348) dated to 892 styles him angol saxonum rex 'King of the Anglo-Saxons'. All charters are cited from The Electronic Sawyer: Online Catalogue of Anglo-Saxon Charters: <http://www.esawyer.org.uk > (accessed $15^{\text {th }}$ July 2015) (S = Sawyer no.). For discussion of the style of this charter, see Snook (2015: 42-43).

49 For discussion of the political implications of these titles, see Pratt (2007a: 105-111); Keynes (2014).

50 See Wood (1983; 2007); Stafford (1989: 33-35); Ortenberg (2010); and Foot (2011: 212-226).

51 See Keynes (2008: 48-51); Molyneaux (2011).

52 See Stenton (1971: 319-373); Sawyer (1998: 121-131); Keynes (2001).

53 Einhard's Vita Karoli Magni, probably written for Louis the Pious c. 817-833, is closely modelled on Suetonius's life of the Emperor Augustus; see Innes (1997). 
less far-reaching, in the ASC's rhetoric the various kings and peoples of Britain effectively acknowledged Edward as their overlord in the 920s. ${ }^{54}$

Though annals are scarcer for Æthelstan's reign, crucial details are provided of the West Saxon dynasty's advance towards imperium over Britain: ${ }^{55}$ ASC 925 (=924) records the smooth transference of power within the West Saxon dynasty from father to son; ASC 933 describes Æthelstan’s successful attack on Scotland by land and sea; and ASC 937 celebrates his victory over a combined force of invading Scots, Strathclyde Welsh and Dublin Norse with a 73-line panegyric poem, The Battle of Brunanburh. The language of this poem recalls the early ASC annals treating both the Anglo-Saxon migration and the Roman conquest of Britain itself: the slaughter at Brunanburh was the greatest on the island since the Angles and Saxons Brytene sohtan 'sought out Britain', Weealles [sic] ofercoman 'conquered the Welsh' and eard begeatan 'won the land' (Bately 1986: 72). ${ }^{56}$ The incorporation of Brunanburh in ASC 937 makes explicit the underlying political message of the more descriptive annals which precede it: the establishment of West Saxon rule over all the peoples and kings of Britain is the culmination of a providential plan for the salvation of the various peoples of the island brought about through contact with Rome.

\section{The Imperial Style of $A$ thelstan}

With the rapid expansion of West Saxon power in the early tenth century came the adoption of glamorous new royal titles: while Edward followed his father in using titles such as Angul saxonum rex 'King of the Anglo-Saxons' (S 369), ${ }^{57}$ rex Anglorum 'King of the Angles' (S 374) ${ }^{58}$ and Edwardus Dei gratia Angolsaxonum rex 'Edward, by the grace of God, King of the Anglo-Saxons' (S 376), ${ }^{59}$ the titles

54 Davidson (2001) downplays the political significance of the "submission" of the northern kings in 920; but Molyneaux has recently emphasized the plausibility of the ASC's claims, arguing: "By the latter years of Edward's reign, it was probably clear that the English king was the most powerful man on the island” (2011: 89).

55 See Foot (2008).

56 See Howe (1989: 31).

57 Charter from Edward to Tatta, his fasallus, 903.

58 Charter from Edward to St Peter's Minster, Winchester, 904.

59 Charter from Edward to the familia of the church at Malmesbury, 901. A charter from Edward to Wulfgar (S 379) dated to 921, styles Edward rex Anglorum per omnipatrantis dexteram totius Britannie regni solio 'King of the Angles, exalted to the right hand of the throne of the kingdom of the whole of Britain', but this charter is thought to be an adaptation of an Æthelstan charter of 933; see Snook (2015: 74). 
used by Æthelstan made grander claims about the extent of West Saxon rule. For example, an inscription in a gospel-book given to Christ Church Canterbury in the early tenth century employs the terminology of Byzantine emperorship in referring to the donator of the book as Aedelstan Anglorum basyleos et curagulus totius Bryttaniae 'Æthelstan Emperor of the English and Guardian of all of the Britons' ${ }^{60}$ Similarly, charters of the 930s refer to Æthelstan as Rex Angulsexna and Norphymbra imperator paganorum gubernator Brittanorumque propugnator 'King of the Anglo-Saxons and Emperor of the Northumbrians, Governor of the Pagans and Defender of the Britons' (S 392), ${ }^{61}$ and brytenwealda ealles Jyses ealondes 'wide ruler of all this island' (S 427), ${ }^{62}$ while coins declare his status as Rex totius Britanniae 'King of all of the Britons' ${ }^{63}$ A short Latin poem by the Frankish poet Petrus commemorating the unification of the island under Æthelstan after the treaty of Eamont in 927 praises the West Saxon king as ruler per totum Bryttanium [...] ista perfecta Saxonia 'throughout all of Britain [...] this Saxony (England?) perfected/made whole' (1. 9-10), noting also that the Scottish king, Constantine, is loyal to Æthelstan's service (fidelis seruitio) (1. 15-16) (Lapidge 1981: 98). ${ }^{64}$ As William Stevenson (1911) noted, Petrus's poem is clearly modelled on a praisepoem dedicated to Charlemagne by a 'Hibernicus exul'. Like the now-lost gesta on which William of Malmesbury based his account of Æthelstan's reign, Petrus presents the West Saxon ruler in the Carolingian imperial style as a king of kings and overlord of a vast realm comprising many peoples. ${ }^{65}$ In terms of dynastic prestige, the tables had now turned significantly in Wessex's favour. While in previous generations, West Saxon kings had sought the hand of Frankish princesses, now ambitious continental aristocrats sought to marry Æthelstan's daughters, ${ }^{66}$ while royal exiles from the remnants of the Carolingian Empire now sought refuge at the West Saxon court. ${ }^{67}$

60 British Library, MS Cotton Tiberius A II; see Keynes (1985: 149); Ortenberg (2010: 215); Snook (2015: 75-76).

61 Grant made by Æthelstan to Byrthelm. See Foot (2008: 140-142).

62 Charter of 934 from Æthelstan to the familia of Holy Trinity, Winchester.

63 See Foot (2011: 151-155). Loyn (1955) argues that such terms had limited constitutional significance; but see now the recent discussion of Molyneaux (2011).

64 On Æthelstan’s patronage of poets, see Foot (2011: 110-117). The treaty of Eamont is described in ASC MS D (the Worcester Manuscript) 926.

65 See Wood (1983: 265-266). On Carolingian ideas of empire, see Nelson (1988: 230).

66 Hence the suits made by Hugh of the Franks and Henry the Fowler (on behalf of his eldest son, Otto).

67 For example Louis, son of the last reigning Carolingian prince, Charles the Simple, king of the West Franks, who had himself married Eadgifu, Edward the Elder’s daughter. On Æthelstan's 
Perhaps the clearest indication of the elevated status which Wessex had now assumed in the eyes of Frankish contemporaries is provided by William of Malmesbury's account of the embassy of Hugh of the Franks to Æthelstan in 926. According to William, the party was led by one Adelolf (named after his greatgrandfather, Æthelwulf of Wessex) bearing lavish gifts, including spices, jewels and horses as well as various items of Carolingian royal regalia, to the West Saxon king (GRA, II.135; Mynors at al. 1998, I: 218-221). ${ }^{68}$ Although William may have embellished the list of gifts, ${ }^{69}$ Michael Wood has argued that the embassy may have effectively constituted a translatio imperii from Carolingian Francia to Wessex: "some of Charlemagne's own divine favour and virtus now passed to Aethelstan, who was certainly entitled to think that there was no continental king to rival him" (1983: 267). ${ }^{70}$ By the early tenth century, West Saxon kings had a better claim to an imperial title than any of their Frankish counterparts, and Veronica Ortenberg has recently asked whether, given the absence of a suitable candidate from the continental branch of the Carolingian house during the 930s, Æthelstan might even have thought about assuming the vacant title of Western emperor himself (2010: 236). In the following section I will explore how OEO might reflect the increasingly imperial ambitions of the West Saxon court in the late ninth and early tenth centuries.

\section{The Reports of Ohthere and Wulfstan and the Extent of West-Saxon Power}

The most substantial expansion to $\mathrm{OH}$, and the first major indication of $O E O$ 's connection to specifically West Saxon royal concerns, occurs in the geographical preface. Orosius's world-view is naturally centred on the Mediterranean and he states that the primary function of his geographical preface is to enable readers to identify the location of disasters caused by war or plague (OH I.1.16; Fear 2010: 35). But this map of the known world also sets the scene for the history of the four

reputation abroad and involvement in continental politics, see Stenton (1971: 346-349); and Foot (2011: 167-169).

68 See Foot (2011: 192-197); Loomis (1950).

69 Foot (2011: 194) notes that the association of the holy lance used to pierce Christ's side with Charlemagne may reflect a tradition which originated in the eleventh century and was utilized by the Ottonians in their claims to emperorship.

70 See further Ortenberg (2010: 222-223); Foot (2011: 197-198). For the Byzantine overtones of Hugh's gifts, see Leyser (1982: 116-117). 
empires, located at the four cardinal points of the world (OH II.1.4-5; Fear 2010: $73-74),{ }^{71}$ around which the main narrative of the Historia is structured. The alterations to the geographical preface in the $O E O$ shift the focus of the work to the north and Britain's place within it, allowing the reader to locate the West Saxon realm and its surrounding regions on the Orosian map. ${ }^{72}$

First OEO adds details about the location of Scotland "Ireland"73 and omits much of Orosius's description of the geography of Asia. ${ }^{74}$ There follows a large expanded section detailing the various rivers and peoples north of the Danube. In both extant manuscripts, this expansion concludes with the famous reports of two northern navigators, Ohthere and Wulfstan, to King Alfred: ${ }^{75}$

Ponne wið norban Donua æwielme $\urcorner$ be eastan Rine sindon Eastfrancan, 7 be supan him sindon Swæfas, on opre healfe pære ie Donua, 7 be supan him 7 be eastan sindon Bægware, se dæl pe mon Regnesburg hætt, 7 ryhte be eastan him sindon Bæme, 7 eastnorp sindon Pyringas, $\urcorner$ be norban him sindon Ealdseaxan, $\urcorner$ be norpanwestan him sindon Frisan. Be westan Ealdseaxum is Ælfe mupa pære ie $\urcorner$ Frisland, $\urcorner$ ponan westnorð is pæt lond pe mon Ongle hæt 7 Sillende $\urcorner$ sumne dæl Dene [...]. Be westan Supdenum is pæs garsecges earm pe lip ymbutan pæt land Brettania, 7 be norban him is pæs sæs earm pe mon hæt Ostsæ, 7 be eastan him 7 be norpan sindon Norðdene, ægper ge on pæm maran landum ge on pæm iglandum [...]. Norðdene habbað be norpan him pone ilcan sæs earm pe mon hæt Ostsæ [...]. Burgendan habbað pone sæs earm be westan him $\urcorner$ Sweon be norpan, 7 be eastan him sint Sermende, $\urcorner$ be supan him Surfe. Sweon habbað be supan him pone sæs earm Osti $\neg$ be eastan him Sermende, 7 be norpan him ofer ba westenne is Cwenland, 7 be westannorpan him sindon Scridefinne 7 be westan Norpmenn.

Ohthere sæde his hlaforde, Alfrede cyninge, pæt he ealra Norðmonna norbmest bude. He сwæð pæt he bude on pæm lande norbweardum wip pa Westsæ. He sæde peah pæt pæt land sie swipe lang norb ponan, ac hit is eal weste, buton on feawum stowum styccemælum wiciað Finnas, on huntoðe on wintra 7 on sumera on fiscape be pære sæ [...]. (Bately 1980a: 12, 1. 24-31; 13, 1. 14-17, 19-20, 22-30; 14, 1.1-4). (Emphasis added)

'Then to the north, from the spring of the Danube, and the east of the Rhine are the East Franks, and to the south of them are the Swabians, on the other side of the river Danube. To the south and to the east are the Bavarians, that part which is called Regensburg, and right to the east of them are the Bohemians, and north-east are the Thuringians. To the north of

71 Unlike most other prefatory sections of $\mathrm{OH}$, this passage is retained and closely translated in OEO II.1, Bately (1980a: 36, 1. 14-19). See further below (pp. 679-688).

72 For discussion of $O E O$ 's rearrangement of geographical centres in the description of northern Europe, see Bately (2014: 328-329).

73 Compare OH I.2.4 (Fear 2010: 36) with OEO I.1 (Bately 1980a: 9, 1. 10).

74 Compare OH I.2.38-50 (Fear 2010: 40-42) with OEO I.1 (Bately 1980a: 12, 1. 1-13).

75 A large portion of this passage, including most of Ohthere's report and all of Wulfstan's, is now missing from the Lauderdale Manuscript due to the loss of fols. 9-16, but the passage is preserved in its entirety in the Cotton Manuscript. 


\begin{abstract}
them are the Old Saxons, and to the north-west of them are the Frisians. To the west of the Old Saxons is the mouth of the river Elbe and Frisland. From there, north-west is the country called Angeln, and Zealand and some part of Denmark [...]. To the west of the South-Danes is the arm of the ocean, which lies around the country of Britain; and to the north of them is the arm of the sea called the Baltic; and to the east and north of them are the North-Danes, both on the continent and on the islands. [...] the North-Danes have to the north of them the same arm of the sea called the Baltic. [...] the Burgundians have the same arm of the sea to the west of them, and the Swedes to the north, and to the east of them are the Sarmatae, and to the south of them the Sorbs. The Swedes have to the south of them the arm of the sea [called] the Osti, and to the east of them the Sarmatae, and to the north of them over that barren land is Cwenland [the land of the Lapps], and north-west of them are the Scridefinne [Lapps] and to their west Northmen [Norwegians].

Ohthere told his lord, King Alfred, that he lived farthest to the north of all the Northmen [Norwegians]. He said that he lived by the western sea in the north part of the land. However, he said that that land extends very much further north; but it is all waste, except Finns [Lapps] camp in a few places here and there, hunting in winter and fishing in the sea in summer [...]'.
\end{abstract}

As Bately (2014: 316) has observed, the transition from the descriptive style of the geographical survey to the reported speech of the Ohthere and Wulfstan section is abrupt and, together with the presence of certain unusual linguistic forms, suggestive of an interpolation. ${ }^{76}$ Bately had initially suggested that this interpolation was made during Alfred's reign by someone connected to his court (1966: 303, n. 291), but subsequently modified this view to propose that the reports may be derived from a document produced at the West Saxon royal court which came to hand as the text was being copied in the early tenth century (1988: 117, n. 143, 118, n. 149). ${ }^{77}$ The reports may have been inserted into $O E O$ simply to supplement the already expanded geographical preface, providing additional information about people, places and customs of the far north, which would have been of obvious interest to Anglo-Saxon readers. ${ }^{78}$

Treating the reports as an interpolation, scholars have tended to read them in isolation from the main body of $O E O$, either as a source of early northern geography (Bately and Englert 2007; Valtonen 2008; Englert and Trakadas 2009) or as evidence for the Anglo-Saxon sense of place (Howe 2008: 113-116; Anlezark

76 Bately (2014: 316) suggests this interpolation may have been "triggered" by the reference to Norpmenn in the expanded section of the geographical description of the north which immediately precedes it.

77 See also Bately (1970: 433; 1980a: lxxii, n. 4; 1980b: 6). For the possibility that the reports are essentially literary fiction, see Tristram (1982); and Godden (2013: 136-137).

78 See Anlezark (2013: 71-80). 
2013). ${ }^{79}$ The presence of the reports in both of our major manuscripts, however, points to its incorporation into $O E O$ soon after the main text's composition. Moreover, there is evidence to suggest that the reports may have been added to $O E O$ during the initial copying of the Lauderdale Manuscript by the same scribe who copied ASC entries for 891-920: as Bately (2014: 342) notes, while elsewhere OEO agrees with two probably late ninth century works, Old English Bede and ASC 891, in referring to Ireland as Scotland, the reports share the spelling Iraland with ASC $914 .^{80}$ For what purpose, then, might this section have been included in $O E O$ and what can its inclusion tell us about how the $O E O$ was read in early tenth century West Saxon court culture?

The $O E O$ differs from the Old English Pastoral Care and Boethius in that it does not feature a preface claiming Alfred as author. However, the introduction of the figure of Alfred as Ohthere's (and, it is usually assumed, Wulfstan's) interlocutor in the geographical preface nonetheless reorients the text to a specifically West Saxon royal perspective in much the same way as the 'West Saxon Genealogical Preface' to the ASC, which traces the history of the West Saxon conquest of Britain from Cerdic and Cynric to Alfred. ${ }^{81}$ By presenting Alfred as a ruler personally interested in increasing the wealth of his realm through trade and actively seeking out knowledge about the northern world, the reports complement the equation of temporal and spiritual wealth and wisdom which scholars have identified in other texts associated with Alfred and his circle (Shippey 1979; Nelson 1986). ${ }^{82}$ Ohthere, perhaps as a gesture of homage to the West Saxon king, presents Alfred with an excellent (æpele) ivory walrus tooth (Bately 1980a: 14, 1. 32), ${ }^{83}$ while claiming to be one of the wealthiest men of Norway with six hundred

79 Kretzschmar (1987: 135) does not discuss the likelihood that the passage is an interpolation and treats it simply as an updating of the geographical information provided by $\mathrm{OH}$.

80 For Iraland, see Bately (1980a: 16, 1.6); Bately (1986: 66). ASC 937 (The Battle of Brunanburh) has Hiraland (Bately 1986: 72).

81 Hurley (2013: 410-411) treats OEO as a text with no preface, and argues that a narrator figure is constructed by the use of the phrase cwæð Orosius 'Orosius said'. On the literary context of Alfredian prefaces more generally, see Godden (2011c). Irvine (2014a) discusses the various prefaces and epilogues which claim Alfred as author or patron of the Dialogues, Pastoral Care, Boethius, Soliloquies, Domboc and Bede.

82 David Pratt has shown how this association of wealth and wisdom in 'Alfredian' writing is itself indebted to Carolingian precedent (Pratt 2007a: 158-162). On the increase in West Saxon maritime trade and sea power in this period, see Maddicott (1989); Lavelle (2010: 141-176, 200-208, 286-298).

83 On the use of ivory bindings in books made as gifts made for Charlemagne, see McKitterick (2008: 349). Bately (1980a: 188) notes: "Walrus tusks were greatly prized for their ivory, and a number of carved objects made of this material have survived from the Middle Ages. An AngloSaxon example is the Gandersheim Casket, probably late eighth century from Ely". 
tame animals unbebohtra [...] ða he pone cyningc sohte 'unbought when he visited that king' (Bately 1980a: 15, 1. 7-8). This image of Alfred at the centre of a new trade network may also serve to connect West Saxon kingship with both Roman and Carolingian precedent: Godden (2011a: 309) has shown how the wealth of Roman emperors is given extra attention in the $O E O$; and prior to the decline of ports such as Dorestad in the ninth century (Reuter 2006), the Carolingian Empire had derived much of its wealth from the same North Sea and Baltic trade routes described by Ohthere and Wulfstan. ${ }^{84}$ So the inclusion of the reports in OEO foregrounds the mercantile ambitions of Wessex, presenting Alfred as a ruler intent on establishing lucrative new trade routes with the north and commanding the respect of wealthy foreign travellers.

The reports also provide important geographical and ethnographic details about the "ancestral homeland" 85 both of Alfred's dynasty and the Angelcynn. The Anglo-Saxons knew from Bede (Historia Ecclesiastica I.15) that they were descended from the continental Angles, Saxons and Jutes. The information which Ohthere provides to Alfred allows English readers of $O E O$ to mentally navigate these regions in relation to the other parts of the Scandinavian-British archipelago: ${ }^{86}$

he cwæð pæt he seglode on fif dagan to pæm porte pe mon hæt æt Hæpum, se stent betuh Winedum 7 Seaxum 7 Angle $\urcorner$ hyrð in on Dene [...] on pæm landum eardodon Engle, ær hi hider on land coman - 7 hym wæs ða twegen dagas on ðæt bæcbord pa igland pe in Denemearce hyrað. (Bately 1980a: 16, 1. 13-15, 18-20)

'he said that he sailed in five days to that port that men call Hedeby, that stands between the Wends and the Saxons and the Angles and belongs to the Danes [...] in those lands dwelt the Angles, before they came here to this land - and for two days those islands that belong to Denmark were on his port side'.

According to Æthelweard's late tenth-century Chronicon, the royal house of Wessex traced its origins to Sceaf's arrival on the Danish island of Skaney (Lat. Scani) (Campbell 1962: 33), the precise location of which is provided by Wulfstan, who states that when he sailed from Hedeby,

Weonoðland him wæs on steorbord, 7 on bæcbord him wæs Langaland 7 Læland 7 Falster 7 Sconeg; 7 pa land eall hyrað to Denemearcan.

84 MacLean (2003: 11) notes that this decline in Carolingian overseas trade was offset by an increase in inland trade and the rise of large towns.

85 I borrow the phrase from Howe (1989: 143-180).

86 See Appleton (2013). 
'Winetland was on his starboard, and on his port side was Langoland and Leyland and Falster and Sconeg [i.e. Skaney], and all that land belongs to Denmark'. (Bately 1980a: 16, 1. 23-25). (Emphasis added)

Comparing the reports' presentation of Alfred as cartographer with Einhard's account of Charlemagne's ownership of maps of Rome, Constantinople and the entire universe (Vita Karoli Magni XXXIII; Thorpe 1969: 89), Fabienne Michelet (2006) argues that Alfred, in mapping the north, symbolically extends West Saxon dominion over the North Sea and the Baltic Sea. Of course, in reality, Alfred could never lay claim to being master of the North Sea, let alone the Baltic. But the reports certainly hint at the expansive outlook of the West Saxon court around the turn of the tenth century. As we shall see below, the main body of the $O E O$ is expressly concerned with the history of the great empires of the world. The positioning of this section in the geographical preface anticipates the pervasive interest in the exercise of royal power displayed throughout the text, inviting readers of the $O E O$ to consider the status of the West Saxon kingdom in relation to the wider narrative of imperial history.

\section{A Note on the Language of Power, Kingship and Empire in the Old English Orosius}

OEO employs a range of terms to denote the related concepts of power, rule, kingdom and empire. The most frequently occurring of these is anw(e)ald/onwald/anwold, which appears in its various forms 128 times in the main text of OEO and 21 times in the section headings ${ }^{87} D O E$ translates this term as "A. power, sovereignty, sway [...]. B. a sovereign's or lord's dominion: realm, domain, empire", ${ }^{88}$ while Bately, in her edition of $O E O$, glosses onw(e)ald, anw(e)ald, anwold as "jurisdiction, rule, power, dominion, empire" (1980a: 384). In the OEO, anweald appears most frequently for Lat. potestas 'power' but is also used to

87 Onwald is the most commonly occurring form, appearing 60 times in OEO Bk VI, against 9 instances of anwald and 2 of anweald. Bately has shown that the section headings are the work of a different author who mechanically copied or summarized the first lines of chapters (1980a: lxxxi-lxxxiii). Anwald/anweald occurs 172 times in the Old English Boethius (B-text), 35 times in the Old English Pastoral Care and 4 times in ASC MS A (912, 914 and 917x2, all entries copied by the scribe associated with the Lauderdale Orosius).

88 DOE notes that the related term ānweald "sole rule, monarchy, absolute power" appears five times in glosses for Latin monarchia. 
translate both regnum 'kingdom'89 and imperium 'empire'. ${ }^{90}$ The compound noun heafod-rice, translated by Bosworth-Toller (s.v.) as "chief kingdom, empire”, is unique to the $O E O$, appearing three times in the main body of the text. The first occurrence renders Latin regnorum principatus 'the principle kingdoms' $(\mathrm{OH}$ II.1.5) as Pas feower heafodricu 'these four chief kingdoms/empires' (Bately 1980a: 36, 1. 14-15). Two subsequent references have no basis in the source: ðas tu heofodricu, Asiria $\neg$ Romana 'those two chief kingdoms/empires, Assyria and Rome' (Bately 1980a: 37, 1. 24-25); hu emnlice pa feower onwealdas para feower heafedrica pisses middangeardes gestodon 'how equally the four powers/dominions of those four chief kingdoms/empires of this world lasted' (Bately 1980a: 132, 1. 25-26). ${ }^{91}$ The frequency with which these terms occur in $O E O$ testifies to the work's pervasive interest in power, kingship and empire.

\section{Rewriting Orosius's Historia as Imperial History}

The clearest indication of the translator's special concern with the history of empires is provided by his treatment of introductory sections and prefaces in which Orosius foregrounds his major themes, often in the form of polemical

89 For example, compare $\mathrm{OH}$ II.3.3: similiter et Roma post annos totidem [...] a Gothis et Alaricho rege eorum, comite autem suo, inrupta et opibus spoliata non regno '[s]imilarly, Rome after the same number of years [...] was stormed by the Goths and Alaric who was their king and a Count of the City. She was stripped of her wealth, but not her kingdom' (Fear 2010: 76; emphasis added) with OEO II.1: Swa eac swilce wearð Romeburg ymb m wintra $\urcorner c\urcorner l x\urcorner$ folneah feower, pætte Alrica hiere ealdormon 7 Gotona cyning hiere onwaldes hie beniman woldon 'So also it happened for the city of Rome around one thousand one hundred and very nearly sixty-four years, that Alaric, her ealdorman and king of the Goths, wished to deprive her of her kingdom' (Bately 1980a: 37, 1. 3334; 38, 1.1; emphasis added).

90 For example, compare $\mathrm{OH}$ VII.8.1: Galba [...] usurpauit imperium[...] septimo mense imperii sui $a b$ Othone iugulatus est 'Galba usurped the empire [...] in the seventh month of his reign he [i.e. Galba] was murdered by Otho' (Fear 2010: 336; emphasis added) with OEO VI. 6: feng Galua se casere to Romana onwalde, pæs on pæm seofeban monðe hiene ofslog Othon an mon, 7 him to pon anwalde feng 'the emperor Galba succeeded to the Roman empire; in the seventh month a man named Otho slew him, and himself succeeded to the empire' (Bately 1980a: 138, 1. 2-4; emphasis added). OE anweald appears, for example, as a gloss on Lat. imperium in Ps. 85.16 in the eleventh-century Vitellius Psalter (Rosier 1962).

91 The latter sentence is paraphrased in the chapter headings: Hu Orosius wæs sprecende ymbe pa iiii onwaldas para feower heafedrica pisses middangeardes 'How Orosius was speaking about the four kingdoms of those four empires of this world' (Bately 1980a: 6, 1. 20-21). 
addresses to the reader. The introductions for Books I (on Creation and the Flood), III (in which Orosius apologizes to his readers for omitting events in the name of concision and explains the purpose of his history), IV (a meditation on the relationship between past and present sorrows), VI (a recapitulation of the introduction to Bk IV) and VII (another polemic directed at Orosius's contemporaries concerning the transformative effect of Christ on human history), are omitted entirely, while the introductions to $\mathrm{OH} \mathrm{Bk}$ II (on the four world empires or heafod-ricu) and Bk V (on the rise of the Roman Empire) are retained and, at times, embellished. Through this radical approach to the introductory sections of each book, $O E O$ shifts the focus of the work from universal to imperial history. So instead of following $\mathrm{OH}$ in beginning with the Creation and Flood ( $\mathrm{OH}$ I.3; Fear 2010: 50), OEO's account of world history opens with the establishment of the Assyrian Empire through the conquests of the wicked king Ninus:

$\mathrm{OH}$ I.4.1-2: Ante annos urbis conditae MCCC Ninus rex Assyriorum 'primus' ut ipsi uolunt propagandae dominationis libidine arma foras extulit cruentamque uitam quinquaginta annis per totam Asiam bellis egit; a meridie atque a Rubro mari surgens, sub ultimo septentrione Euxinum pontum uastando perdomuit [...].

' 1,300 years before the foundation of the City, Ninus the 'first' (as they would have it) king of the Assyrians, took up arms out of lust to spread power abroad and lived a bloodstained life, spreading war across all of Asia for 50 years. Rising up from the south by the Red Sea, he laid waste and brought under his sway the far-flung shores of the Euxine Sea [...]'. (Fear 2010: 51). (Emphasis added)

OEO I.2: Ær ðæm Romeburh getimbred wære brim hund wintra 7 pusend wintra, Ninus, Asyria kyning, ongan manna ærest ricsian on ðysum middangearde. 7 mid ungemætlicre gewilnunge anwaldes he wæs heriende $\urcorner$ feohtende fiftig wintra, oð he hæfde ealle Asiam on his geweald genyd suð fram bæm Readan Sæ 7 swa norð op pone sæ pe man hæt Euxinus [...]..$^{92}$ (Bately 1980a: 21, 1. 23-28).

' 1300 years before the city of Rome was built, Ninus, king of Assyria, began as the first of men to rule in this world. And with immeasurable desire for power he was harrying and attacking for 50 years, until he had brought all of Asia under his power, south from the Red Sea and north as far as that sea that men call the Euxine [...]'. (Emphasis added)

The transformation of Orosius's sceptical treatment of the claim that Ninus was the first king of the Assyrians into the much more emphatic statement that he

92 Hurley (2013: 408) notes: "The dating of each event in the Orosius in terms of the founding of Rome suggests continuity between the Roman Empire and the Anglo-Saxons, who were partial inheritors of the Roman tradition of historiography". 
ongan manna ærest ricsian on yysum middangearde 'began as the first of men to rule in this world' suggests that $O E O$ will aim to provide a history of the institution of kingship itself; $\mathrm{OH}$, by contrast, presents a history of the world in which empires play a key structural role. ${ }^{93}$ Moreover, OEO also rearranges the syntax used to describe the extent of Ninus's geweald, reinforcing the connection between mapping and empire building suggested by the reports of Ohthere and Wulfstan: where $\mathrm{OH}$ has Ninus himself emerging from the south by the Red Sea and bringing the shores of the Euxine Sea under his sway, OEO instead maps the territory which he conquered ("fram pæm Readan Sæ 7 swa norð op pone sæ pe man hæt Euxinus"). ${ }^{94}$ If we treat the navigators' reports as an integral part of $O E O$ as it was read in the early tenth century, then we find at the chronological extremes of imperial history two rulers extending their dominion over foreign lands: Ninus and Alfred. The main body of $O E O$ develops a framework for understanding the essential differences between these two rulers and, by implication, the contrasting fates of their respective kingdoms.

The early parts of $\mathrm{OH} \mathrm{Bk}$, sketching the history of the Assyrian Empire, are reproduced without major alteration in $O E O$, suggesting that this section was of some interest to the translator and his intended readers. In this litany of natural disasters and crimes, God is shown to have punished those who disobey his laws (e.g. Sodom and Gomorrah, Babylon, Egypt), and the first great empire of the world ends ignominiously with the murder of its last king:

$\mathrm{OH}$ I.12.2, 10: nam cum regnum Assyriorum per MCLX annos usque ad Sardanapallum per quinquaginta propemodum reges actum sit et numquam paene uel inferendis uel excipiendis usque ad id tempus quieuerit [...] conici datur, qualiter homines sustinuerint, quod etiam astra fugisse dicuntur.

'For since the kingdom of the Assyrians lasted for 1,160 years down to the time of Sardanapulus, was ruled by almost 50 kings, and since during that time war was almost always being waged either against them or by them [...]. We might wonder how men could endure that from which they say even the stars fled'. (Fear 2010: 62-63)

93 Fear (2010: 51, n. 139) notes that Orosius's main source here is Justin's Epitome of Trogus, I.12. Justin describes Ninus as the first king who forged a substantial empire, breaking from the earlier custom according to which kings defended, rather than advanced, the borders of their own territory. For the text, see Yardley (1994: 14). Augustine quotes Justin in City of God IV.6, describing Ninus as "the first ruler to extend his dominion by making war on his neighbours" (Bettenson 1972: 141), and castigating him for his lust for power.

94 Compare, for example, the expanded description of northern geography: 7 be norpan him is pæs sæs earm pe mon hæt Ostsæ, 7 be eastan him 7 be norpan sindon Norðdene 'and to the north of them is that sea's arm that men called the East Sea, and to the east of them and to the north are the North-Danes' (Bately 1980a: 13, 1.15-16). 
OEO I.8: pe Asyrie hæfdon lx wintra 7 an hund 7 an pusend under fiftiga cyninga rice, pæt hit na buton gewinne næs op pæt Sarðanopolim ofslegen wearð, 7 se anwald siððan on Мæðе gehwearf [...]. On pæm dagum wæron swa ungemetlica yfel pæt ba men sylf sædon pæt hefones tungul hiora yfel flugon. (Bately 1980a: 27, 1. 23-26; 28, 1. 9-10).

'The Assyrians had rule for 1160 years under 50 kings, so that it was never without war until Sardanapulus was slain, and the empire afterwards passed to the Medes [...]. In those days evils were so unbounded that men themselves said that the stars of heaven fled from their evil'. (Emphasis added)

The small Old English expansion here, noting that after the death of Sardanapulus anwald passed from Assyria to Medes, again reinforces the theme of translatio imperii, directly connecting the wickedness of the pagan rulers with the loss of their power.

Between the demise of the Assyrian Empire and the rise of Medes, Orosius describes the conquests of the terrifying Amazonian women ( $\mathrm{OH}$ I.15-16, translated in $O E O$ I.10), and the arrival of the Goths in central Europe. Here again we notice a significant departure from the source which appears to reflect contemporary political and ethnographic concerns. Whereas Orosius, writing not long after the sack of Rome in 410, writes of the Goths in fearful terms ( $\mathrm{OH}$ I.17.2; Fear 2010: 66), OEO describes them as coming of pæm hwatestan monnum Germania 'from the bravest people of Germania' (OEO I.10; Bately 1980a: 30, 1. 34-35). As Harris (2001) and Godden (2002) have noted, this alteration may be accounted for by the facts that the Anglo-Saxons, as a Germanic people, identified ethnically with the Goths and, more specifically, that the West Saxon dynasty itself was thought to have Gothic roots. ${ }^{95}$

To Orosius's abbreviated account of the evils of the Trojan War, OEO adds little, though the account of the rise of the Medan Empire, following the demise of Assyria, is similarly characterised by bloodshed and suffering. But the omission of Orosius's reference to power changing hands between the Scythians and Chaldeans before eventually returning to the Medes ( $\mathrm{OH}$ I.19.2; Fear 2010: 67) creates a smoother impression of translatio imperii from Assyria to Medes, as does the inclusion of a comment on the transference of anwald from Medes to Cyrus and Persia in OEO's account of the fall of the Medan Empire:

95 Asser (De Rebus Gestis AElfredi II), for example, records that Alfred's mother, Osburh, was the daughter of Oslac, Gothus erat natione 'a Goth by race' (Stevenson 1959: 4; Keynes and Lapidge 1983: 68). 
$\mathrm{OH}$ I.19.10-11: is finis imperii Medorum fuit. ${ }^{96}$ sed ciuitates, quae tributariae Medorum erant, a Cyro defecerunt: quae res Cyro multorum bellorum causa et origo exstitit.

'This was the end of the empire of the Medes. But the cities that had paid tribute to the Medes now defected from Cyrus, something which cost him many wars'. (Fear 2010: 68)

OEO I.12: Đær wearð Mæðe onwald geendod. Ac Cirus mid Perseum to ðæm anwalde feng. Ac pa byrig pe on monegum peodum Mæðum ær gafol guldon wurdon Ciruse to monegum gefeohtum..$^{97}$ (Bately 1980a: 33, 1. 30-33). (Expansion indicated by italics)

'There the empire of Medes was ended. But Cyrus with the Persians received that empire. But the towns that in many regions previously had yielded tribute to the Medans became (the cause of) a great many battles for Cyrus'. (Expansion indicated by italics)

But the clearest indication of OEO's special concern with translatio imperii is, as noted above, provided by the retention and expansion of the introductions to $\mathrm{OH}$ Bk II and Bk V, both of which focus explicitly on the history of empires. While all the other introductory sections of $\mathrm{OH}$ are substantially cut, in the opening of Bk II OEO carefully follows Orosius in emphasizing the continuing role of Providence in deciding the fates of kingdoms and empires, underlining the relevance of this teaching to contemporary Anglo-Saxon culture through the addition of selfassertive personal pronouns and the deictic nu:

$\mathrm{OH}$ II.1.3: quapropter omnem potestatem a Deo esse omnemque ordinationem, et qui non legerunt sentiunt et qui legerunt recognoscunt. quod si potestates a Deo sunt, quanto magis regna, a quibus reliquae potestates progrediuntur.

'Therefore, all power and order comes from God. Those who have not read this, feel it to be the case, and those who have read it, recognize it to be so. And if powers come from God, this is all the more the case with kingdoms from which all other power proceeds'.

OEO II.1: Nu we witon pæt ealle onwealdes from him sindon, we witon eac bæt ealle ricu sint from him, for pon ealle onwealdes of rice sindon. (Bately 1980a: 36, 1. 7-9). ${ }^{98}$

'Now we know that all power is from Him, we also know that all kingdoms are from Him, because all power comes from a kingdom'. (Emphasis added)

96 Fear (2010: 68, n. 222) notes that Orosius follows Justinian here.

97 The fall of the Medan Empire is given extra emphasis in $O E O$ through the addition of a rhetorical flourish midway through the account of the decisive battle with the Persians: 7 on pæm gefeohte Meða cræft 7 heora duguð gefeoll 'and in that battle the might of Medes and their nobility fell' (OEO I.12; Bately 1980a: 33, 1.12).

98 Cf. Romans 13.1. 
Statements such as this invite $O E O$ 's readers to recognize the recent conquests of the West Saxon kings as a manifestation of God's favour, and to be thankful for the fact that, unlike less fortunate peoples of the past, they have good Christian kings to rule over them.

The difference between past and present times, a recurring theme of $\mathrm{OH}$, is given greater prominence in $O E O$ through numerous expansions, ${ }^{99}$ including observations contrasting the fates of pagan and Christian kingdoms. For example, $O E O$ places greater emphasis than $\mathrm{OH}$ on God's role in allowing rulers to maintain anwald in reward for their observance of Christian customs, in a passage comparing and contrasting the rise and the fall of Babylon and Rome:

$\mathrm{OH}$ II.3.6-7: ecce similis Babyloniae ortus et Romae, similis potentia, similis magnitudo, similia tempora, similia bona, similia mala; tamen non similis exitus similisue defectus. illa enim regnum amisit, haec retinet; illa interfectione regis orbata, haec incolumi imperatore secura est. et hoc quare? quoniam ibi in rege libidinum turpitudo punita, hic Christianae religionis continentissima aequitas in rege seruata est; ibi absque religionis reuerentia auiditatem uoluptatis licentia furoris impleuit, hic et Christiani fuere, qui parcerent, et Christiani, quibus parcerent, et Christiani, propter quorum memoriam et in quorum memoria parceretur.

'Behold, how Babylon and Rome had a similar beginning, similar power, a similar size, a similar age, similar goods, and similar evils, but their ends and decline are not similar. Babylon lost her kingdom; Rome retains hers. Babylon was left an orphan on the death of her king, Rome is secure and her emperor safe. And why has this happened? Because there punishment for its disgraceful lusts was visited upon the person of the king, but here the restrained moderation of the Christian Religion was preserved in the person of the king. There, where there was no reverence for religion, licentious frenzy eagerly took its fill of desires; here there were Christians who gave pardon, Christians who were pardoned, and Christians through whose memory and in whose memory pardon was given'. (Fear 2010: 77)

OEO II.1: Hu gelice onginn pa twa byrg hæfdon, $\rceil$ hu gelice heora dagas wæron, ægðer ge on ðæm gode ge on ðæm yfele! Ac hiora anwalda endas wæron swipe ungelice; for pon pe Babylonie mid monigfealdum unryhtum 7 firenlustum mid heora cyninge buton ælcre hreowe libbende wæran, pæt hie hit na gebetan noldan ær pon hie God mid pæm mæstan bismere geeaðmedde, pa he hie ægðres benam ge heora cyninges ge heora anwaldes. Ac Romane mid hiora cristnan cyninge Gode peowiende wæron, pætte he him for pæm ægpres geupe, ge hiora cyninges ge heora anwaldes. (Bately 1980a: 38, 1. 16-24).

99 See, for example, the comment added to the account of the Trojan War: Gepence ponne para tida 7 n pissa, hwæðre him bet licien! 'Think then of those times and now of these, which should please them the better!' (OEO I.11; Bately 1980a: 32, 1. 7-8). See also OEO I.10; Bately 1980a: 30, 1. 24; 31, 1. 1-22). 


\begin{abstract}
'How alike were the beginnings of the two cities, and how alike were their days, both in good and evil! But how very unalike were the ends of their empires; because the Babylonians were living with manifold injustices and sinful pleasures with their king, without any remorse, so that they would not make amends for it until God humbled them with the greatest disgrace, when He deprived them both of their king and their empire. But the Romans, with their Christian king, were serving God, so that He granted them for that both their king and their empire'. (Emphasis added)
\end{abstract}

Alfred uses similar rhetoric in his Preface to the Old English Pastoral Care, which laments the recent witu 'punishments' which have befallen the Angelcynn because of their un-Christian conduct, reminding his readers, the English bishops, of the success of earlier English kings who obeyed the church's teaching:

[A]nd hu ða kyningas ðe ðone onwald hæfdon ðæs folces on ðam dagum Gode and his ærendwrecum hiersumedon; and hie ægðer ge hiora sibbe ge hiora siodo ge hiora onweald innanbordes gehioldon, and eac ut hiora eðel gerymdon; and hu him ða speow ægðer ge mid wige ge mid wisdome. (Sweet 1871-1872: 3, 1. 5-9)

'And how the kings that had the power over that people in those days obeyed God and His messengers, and they kept their peace and their morality and their power within the borders, and also they extended their territory abroad; and how they prospered both with warfare and wisdom'.

In Alfred's rhetoric, Wessex must follow the example of these earlier Christian Anglo-Saxon kings in order to succeed in war and wisdom; failure to obey God's messengers will lead to a loss of power (anwald) at home and prevent kings from extending their territory (eðel) abroad. ${ }^{100}$ By the early tenth century, in Orosian terms, Wessex could reflect on how God had now rewarded its kings for their piety by permitting them not only to maintain their grip on power in the face of invasion but also to establish overlordship across much of the island.

The image of West Saxon kings as merciful, Christian lawgivers may lie behind an 'authorial' comment in OEO's account of the wicked prince Phalaris. Where $\mathrm{OH}$ simply comments that Christian rulers ne ipsorum quidem iniurias exigunt tyrannorum 'do not even punish the injuries done to them by tyrants' (OH I.20.6; Fear 2010: 69), OEO offers a more extensive appraisal of the clemency of contemporary rulers: 7 nu cyningas 7 caseras, peah pe hwa wið hiora willan gegylte, hie ðeah for Godes lufan be ðæs gyltes mæpe forgifnesse doð 'and now kings and emperors, if that

100 I follow here Sweet's translation of eðel as “territory” (1871-1872: 2). DOE has “1. one’s own country, one's true home [...]. 1.a. home, homeland, land of one's birth, (hereditary) land, (ancestral) domain". 
anyone should become guilty against them, they for the love of God grant forgiveness for that crime' (OEO I.12; Bately 1980a: 34, 1. 18-20; emphasis added). Early Anglo-Saxon law had made some provision for kings to pardon criminals, ${ }^{101}$ but the theme of royal mercy figures particularly prominently in West Saxon lawcodes from the late ninth century onwards, most notably in the so-called Mosaic Preface to Alfred's lawcode, which lays special emphasis on the need for legislators to display the mildheortnesse pe Crist lærde 'clemency which Christ taught' when dealing with any crime save plotting against a lord (Liebermann 1903: 44). ${ }^{102}$

The benefits of (contemporary) Christian kingship are further exemplified in OEO's expanded account of the wicked treatment of foreigners by the Egyptian King Busiris. In a series of rhetorical questions, the English translator, speaking in the voice of Orosius, ${ }^{103}$ highlights the improved lot of peoples living within cristendom:

OEO I.8: Ic wolde nu, cwæð Orosius, pæt me ða geandwyrdan pa pe secgað pæt peos world sy nu wyrse on ðysan cristendome ponne hio ær on pæm hæpenscype wære, ponne hi swylc geblot 7 swylc morð donde wæron swylc her ær beforan sæde. Hwær is nu on ænigan cristendome betuh him sylfum pæt mon him purfe swilc ondrædan, pæt hine mon ænigum godum blote? oððе hwær syndon ure godas pe swylcra mana gyrnen swilce hiora wæron? (Bately 1980a: 27, 1. 11-17)

'I now wish to know, said Orosius, that they would answer me, those that say that this world is now worse in these Christian times than she was before in those heathenish times, when they made such sacrifices and such murder as was said here before. Where is there now, in all of Christendom, that, among themselves, anyone needs to fear such things, that someone might sacrifice him to any gods? And where are our gods that desire such wickedness as theirs?'

While Busiris murdered foreigners who ventured into his kingdom, Alfred, by contrast, famously sought them out in order to gain wisdom, both for his own benefit and that of his subjects: in addition to the account of the visit(s) of Ohthere and Wulfstan contained in the geographical preface to the OEO itself, ASC 891, for example, records the arrival of Irish clerics at his court, while Asser (De Rebus

101 For example, Ine 36.1 states that an ealdorman may be pardoned by the king for allowing a thief to escape (Liebermann 1903: 104).

102 Although Æthelstan's laws are characterized by their obsessive concern with punishment for theft, III Æthelstan 3, issued by the bishops and councillors in Kent c. 928-938, thanks the king super dono quod forisfactis hominibus concessisti 'for the pardon you have granted all criminals', on the grounds that they swear not to reoffend and confess and make amends (Liebermann 1903: 170); similarly, VI Æthelstan 12.1-3 notes the king’s personal intervention in preventing the execution of youths under the age of 15 and those guilty of minor offences (Liebermann 1903: 182-183).

103 On this feature of $O E O$, see Godden (2007: 7); Hurley (2013). 
Gestis Alfredi LXXVII-LXXIX) describes the king's eagerness to recruit scholars from all over northern Europe (Stevenson 1959: 62-65; Keynes and Lapidge 1983: 92-94, 103). ${ }^{104}$

The implicit identification of late Roman, Christian emperorship and contemporary (West-Saxon) kingship in OEO can also be detected in two further passages in the introduction to Bk II, in both of which the English author, again closely following $\mathrm{OH}$, refers to the Roman Empire in the present tense:

$\mathrm{OH}$ II.1.4-5: a principio Babylonium et deinde Macedonicum fuit, post etiam Africanum atque in fine Romanum quod usque ad nunc manet, eademque ineffabili ordinatione per quattuor mundi cardines quattuor regnorum principatus distinctis gradibus eminentes, ut Babylonium regnum ab oriente, a meridie Carthaginiense, a septentrione Macedonicum, ab occidente Romanum [...].

'In the beginning, this was the kingdom of Babylon, then the kingdom of Macedon, after that the African kingdom, and finally that of Rome, which until now remains. Through this same ineffable ordering of things, the four principal kingdoms which have been pre-eminent to differing degrees, have occured at the four cardinal points of the world: the Babylonian kingdom to the east; to the south the Carthaginian; to the north the Macedonian; and to the west the Roman'. (Emphasis added)

$\mathrm{OH}$ II.3.3: et opibus spoliata non regno, manet adhuc et regnat incolumis [...].

'She [Rome] was stripped of her wealth but not her kingdom - for she still remains and rules in safety'. (Fear 2010: 76). (Emphasis added)

OEO II.1: An wæs Babylonicum, pær Ninus ricsade. pæt oðer wæs Creca, pær Alexander ricsade. Pridda wæs Affricanum, pær Ptolome ricsedon. Se feorða is Romane, pe giet ricsiende sindon. Pas feower heafodricu sindon on feower endum byses middangeardes mid unasecgendlicre Godes tacnunge. Pæt Babylonicum wæs pæt forme 7 on easteweardum. pæt æfterre wæs pæt Crecisce 7 on norðeweardum. pæt pridde wæs pæt Affricanum 7 on suðweardum. Pæt feorpe is Romane 7 on westeweardum [...] ac hie nugiet ricsiende sindon ægper ge mid hiera cristendome ge mid hiora anwalde ge mid hiera caserum. ${ }^{105}$ (Bately 1980a: 36, 1. 12-19; 38, 1. 7-9).

'The first [empire] was the Babylonian, where Ninus ruled, then the next was the Grecian, where Alexander ruled. The third was the African, where the Ptolemies ruled. The fourth is

104 Æthelstan's retinue included Irishmen, Franks and Saxons. Moreover, William of Malmesbury records that two Norwegian ambassadors, Helgrim and Osfrid, arrived at Æthelstan's court bearing gifts from Harald Fairhair, King of Norway, who was seeking an ally in his own struggles against the Vikings, while the tradition that Harald's son, Hákon, was fostered at Æthelstan's court is attested in several Scandinavian sources dating from the twelfth century (Stenton 1971: 349-350; Wood 2010; Foot 2011: 54-55).

105 On the use of the term cristendom in OEO, see Harris (2001). 
the Roman, which is still ruling yet. These four empires are in the four ends of this world through the unspeakable Providence of God. That Babylonian [empire] was that first in the east. The one after that was that Grecian [empire], in the north. The third was that African [empire], in the south. The fourth is the Romans in the west [...] because of their Christendom, God did not allow it, neither for their emperors nor themselves, and they [the Romans] are still reigning yet, as much with their Christendom/Christian rulers as with their empire and with their emperors'. (Emphasis added)

Nicole Guenther Discenza has commented that this passage leaves "no room for more empires", arguing that "Britain holds no interest for the first three and only slight interest for the fourth (i.e. the Roman empire)" (2006: 91). However, this statement on the longevity of Rome, the fourth heafodrice 'empire', may in fact have been directly relevant to Anglo-Saxon politics, if viewed from an early tenthcentury perspective in the context of a translatio imperii from Francia to Wessex. Moreover, as Kretzschmar has noted, the English translator contradicts Orosius's statement that God ordained a cycle of four empires which began with Babylon and ended with Rome (1987: 142), ${ }^{106}$ pointing instead to the continuing rise and fall of empires in his own day in a passage with no counterpart in $\mathrm{OH}$ :

ic wolde [...] eac pæt hie oncnewen hu gelimplice ure God on pæm ærran tidum pa anwaldas 7 ba ricu sette, se ilca se pe giet settende is 7 wendende ælce onwaldas 7 ælc rice to his willan. (Bately 1980a: 38, 1. 10-16).

'And I would make it known [...] also that they should know how seasonably our God set the empires and kingdoms in those days, that same one that is still setting and changing each empire and each kingdom according to His will'. (Emphasis added)

Echoing Jerome's interpretation of Daniel II, the translator may have had in mind here the rise and fall of the Anglo-Saxon kingdoms of the heptarchy before the ninth-century West Saxon supremacy, or even the recent failure of the Vikings themselves to establish a lasting empire in Britain. However, read in an early tenth-century context, this passage may also have been understood as gesturing towards the demise of the Carolingians, self-styled inheritors of the Roman imperial idea, and the synchronous rise of Wessex to overlordship in Britain. ${ }^{107}$

$106 \mathrm{OH}$ II.3.5: et in principio Babyloniis et in fine Romanis 'and in the the beginning the Babylonian [empire] and in the end the Roman [empire]'.

107 OEO closely follows $\mathrm{OH}$ in emphasizing the synchronicity of the fall of one empire with the rise of another, however protracted this might be. Compare $O H$ II.2.2-10 (Fear 2010: 74-75) with OEO II.1 (Bately 1980a: 36, 1. 29-30, and 37, 1. 9-12, 16-21). See further Van Nuffelen (2012: 49-50). 
In a recent study, Omar Khalaf argues that $O E O$ 's “re-elaboration” of $O H$ 's section on Alexander the Great transforms him into "an exemplary model of what a leader must and must not do in the exercise of power", a manoeuvre which is "fully conscious and in line with Alfred's cultural and political programme” (2013: 207208). ${ }^{108}$ In addition to the exemplary figure of Alexander himself, however, $\mathrm{OH}^{\prime}$ 's account of the end of the Macedonian Empire also provides an instructive example of the problems that can beset a royal dynasty following the death of a great king:

$\mathrm{OH}$ III.23.1, 6: At ego nunc reuocor [...] quae inter se bella gesserint Macedonum duces reuoluam, qui mortuo Alexandro diuersas sortiti prouincias mutuis se bellis consumpserunt. [...] Igitur Alexander per duodecim annos trementem sub se orbem ferro pressit, principes uero eius quattuordecim annis dilaniauerunt et ueluti opimam praedam a magno leone prostratam auidi discerpsere catuli, seque ipsos inuicem in rixam inritatos praedae aemulatione fregerunt.

'I shall now call myself back in order to go through the wars that the leaders of the Macedonians fought among themselves [...] and relate how on the death of Alexander, they drew lots for the various provinces and then destroyed themselves by infighting. [...] After Alexander had crushed the trembling world beneath his sword for twelve years, his generals tore it asunder for another fourteen and, like lion-cubs eager to tear apart the rich prey brought down by a great lion, destroyed one another by quarrelling among themselves in their eagerness for the prize'. (Fear 2010: 145-146)

OEO III.11: Ic sceal eac gemyndgian be sumum dæle pæs pe Alexandres æfterfylgendas dydon on pæm tidun [...] hie hie selfe mid misselican gefeohtum fordydon. [...] Alexander xii gear pisne middangeard under him prymsde 7 egsade, 7 his æfterfolgeras feowertiene gear hit sippan totugon 7 totæron pæm gelicost ponne seo leo bringð his hungregum hwelpum hwæt to etanne: hie ðonne gecyðað on ðæm æte hwelc heora mæst mæg gehrifnian. (Bately 1980a: 77, 1. 8-10, 19-23).

'I must also recall, in part, what Alexander's successors did in those times [...] how they destroyed themselves in various battles. [...] Alexander crushed and terrified this world under him for twelve years, and his successors for fourteen years afterwards pulled and rent it apart most like when the lioness brings something to eat to its hungry whelps, then they show in that food which of them can be gorged the most'. (Emphasis added)

As we have seen, both Regino and ASC 887 record how the formerly unified Carolingian realm was similarly broken into warring factions following the death of Charles the Fat. The translation of the Latin duces 'leaders' and principes 'generals' as OE æfterfylgendas and æfterfolgeras 'successors' makes the crisis

108 Of course, such concerns would have been equally relevant during the reigns of Alfred's successors, who were, if anything, more successful as military leaders. 
following Alexander's death seem like more of a dynastic struggle than a purely military one. For the West Saxon court, the lesson to be learned from these accounts of the end of earlier empires is plain: unless the royal succession is carefully planned, the death of a king can lead rapidly to the break-up of the realm. Alfred himself appears to have taken extensive measures to ensure that, following his death, the throne would pass directly to his son, Edward the Elder (Yorke 2001: 31-32). But according to ASC 900, 903 and 904, the ætheling Æthelwold, a son of Alfred's brother, King Æthelred I, led a violent (though ultimately unsuccessful) revolt against Edward, with the support of the Danes of Northumbria and East Anglia. ${ }^{109}$ So for an early tenth century reader of $O E O$, the dangers of infighting among the royal kin over the succession, and the threats this might pose to the survival of anwald, would have been readily apparent.

\section{The Fall of Rome, the Punic Wars and the Viking Invasions}

The translator's decision to omit most of $\mathrm{OH}$ Bk VII, describing the sack of Rome by the Goths in 410, has long puzzled critics. This may be partly accounted for by the fact that, as Dorothy Whitelock argues, the cause of the fall of Rome "was not a burning question by Alfred's reign" (1966: 90). ${ }^{110}$ But temporal distance alone cannot fully explain the translator's remarkably perfunctory treatment of this key section of his source, particularly considering the substantial space devoted in the preceding chapters to the falls of the even more ancient empires of Babylon, Macedon and Carthage. Moreover, as Lucrezia Pezzarossa (2013: 226) has recently observed, the presentation of the Goths as 'gentle', Christian conquerors throughout $O E O$ is "deeply problematic" if seen from an Alfredian perspective, considering the general presentation of the Vikings in contemporary West Saxon texts as murderous heathens. As we have seen, Godden (2002: 68) accounts for OEO's downplaying of Gothic violence on the grounds of the Anglo-Saxon sense of shared ethnicity, ${ }^{111}$ while in a more recent article he suggests that "contemporary topical reference" was not on the translator's mind when he was working on this section of $O H$ (2011b: 27). The fact that $O E O$ cuts far less from the earlier books of

109 See Stenton (1971: 321-322).

110 This view is reiterated by Bately (1980a: xciv).

111 In the same article, Godden (2002: 59-60) discusses the significance of the contrasting endings to $\mathrm{OH}$ (in which the Goths are expelled from Narbonne into Spain) and $O E O$ (in which they settle in Italy). 
$\mathrm{OH}$ describing the rise and fall of the first three empires therefore becomes all the more significant, suggesting that this part of Orosius's work was of more interest to a contemporary Anglo-Saxon audience than the crisis of the early fifth century. Indeed, the narrator of $O E O$ often plainly spells out the relevance of these earlier books to the political situation of the present day. For example, as Bately notes, the 'authorial' comments, with no basis in $\mathrm{OH}$, which appear at the end of Book III, following the account of the wars among Alexander's successors, are almost certainly an allusion to the Anglo-Saxons' struggles with the Vikings (1980a: 270):

OEO III.11: [...] hit is us nu swipor bismre gelic pæt we pæt besprecað, ๆ pæt pæt we gewinn $n u$ hatað, ponne $u$ s fremde $\urcorner$ ellpeodge an becumap $\neg$ lytles hwæt on us bereafiað $\neg$ us eft hrædlice forlætað [...]. (Bately 1980a: 82, 1. 33; 83, 1. 1-3).

'[...] It is greatly shameful for us now that we speak of that, and that which we now call strife, when strangers and foreigners come to $u$ s and rob us of a little and then afterwards quickly abandon $u s[$ [...]'. (Emphasis added)

By shifting the focus of the text from Rome's fall to its rise, the $O E O$ provides an instructive historical precedent for the rise of Wessex to overlordship in Britain. I would suggest that Orosius's detailed account of the successful defence of Rome against the invading Carthaginians during the Second Punic War (OH IV.8-10) provided the English translator with a much more serviceable analogy for the defence of Wessex against the Vikings than did Orosius's later account of the fall of Rome to the Goths in 410. Orosius's Carthaginians, a savage people led by power-mad kings, resemble in some ways the ASC's portrayal of the micel here. For example, where $\mathrm{OH}$ criticizes the Carthaginians for "the shameful disgrace of breaking their treaty" with Rome by aiding the Tarentines (IV.5.2; Fear 2010: 161), OEO adds that they broke aðas 'oaths' made to the Romans, ${ }^{112}$ echoing the ASC's presentation of the Vikings as deceitful oath-breakers. ${ }^{113}$

The translator also appears to have perceived in Orosius's account of the heroic leaders of the Roman resistance to the Carthaginian invasion a model worthy of imitation by contemporary rulers and ealdormen. Hence, for example, he expands a passage in which the composite figure of 'Scipio'114 makes the Romans swear aðas that they will never leave their homeland on pain of death, emphasizing the need for national unity in the face of invasion:

112 Bately (1980a: 87, 1. 14-16). Godden (2011b: 308) notes similarities between this passage in $O E O$ and a gloss in a Frankish copy of $O H$, St Gall MS 621; Bischoff (2014: 133) dates this manuscript to the early tenth century.

113 See, for example, ASC 876 (=875), 878, 894 (=893), 918 (=917), 921 (=920).

114 See Godden (2011b: 319). 
$\mathrm{OH}$ IV.16.6: usque adeo autem ultima desperatio reipublicae apud residuos Romanos fuit, ut senatores de relinquenda Italia sedibusque quaerendis consilium ineundum putarint. quod auctore Caecilio Metello confirmatum fuisset, nisi Cornelius Scipio tribunus tunc militum, idem qui post Africanus, destricto gladio deterruisset ac potius pro patriae defensione in sua uerba iurare coegisset.

'Despair for the republic reached such depths among the surviving Romans that the Senate thought that a plan to abandon Italy and seek a new home ought to be considered. This motion, proposed by Caecilius Metellus, would have been passed, had not Cornelius Scipio, the same who was afterwards to be called Africanus, but who at that time was a military tribune, drawn his sword, frightening them from putting the motion to the vote and forcing them instead to swear to defend their country'. (Fear 2010: 186-187)

OEO IV.9: [...] he his sweorde gebræd 7 swor ðæt him leofre wære pæt he hiene selfne acwealde ponne he forlete his fæder oepel; 7 sæde eac pæt he para ælces ehtend wolde beon swa swa his feondes, pe pæs wordes wære pæt from Romebyrg pohte. 7 he hie ealle mid pæm geniedde pæt hie apas sworan pæt hie ealle ætgædere wolden, oppe on heora earde licggean, oppe on heora earde libban. (Bately 1980a: 101, 1. 2-31).

'He [i.e. Scipio] drew his sword and swore that he would rather that he should kill himself than that he should abandon his fatherland; and he also said that he would be the pursuer (in vengeance) of each of those, just as he would his enemy, that were of the opinion that thought to go from the city of Rome. And he thereupon pressed them all so that they swore oaths that they would all be gathered together, either to lie dead in their land, or to live in their land'. (Emphasis added)

In the same section, the translator adapts Orosius's account of the heroic resistance of Claudius Marcellus, omitting irrelevant details such as the names of the consuls who were ruling at the time (and transforming Marcellus himself into a consul), but emphasizing his use of stealth to defeat the invading army:

$\mathrm{OH}$ IV.16.12: Deinde Sempronio Graccho Q. Fabio Maximo consulibus Claudius Marcellus expraetore proconsule designatus Hannibalis exercitum proelio fudit primusque post tantas reipublicae ruinas spem fecit Hannibalem posse superari.

'Then, in the consulate of Sempronius Gracchus and Quintus Fabius Maximus, Claudius Marcellus, a former praetor and proconsul designate, fought Hannibal's army and put it to flight. After so many disasters had been suffered by the republic, he was the first to give hope that Hannibal could be beaten'. (Fear 2010: 187)

OEO IV.9: Æfter pæm Romane gesetton Claudius Marcellus to consule, se wæs ær Scipian gefera. He for dearnenga mid gewealdene fultume on pone ende Hannibales folces pe he self on wæs 7 fela pæs folces of $f l o g\rceil$ hiene selfne gefliemde. Pa hæfde Marcellus Romanum cuð gedon pæt mon Hannibal geflieman mehte, ðeh pe hie ær tweode hwæðer hiene mon mid ænige monfultume geflieman mehte. (Bately 1980a: 102, 1. 17-23). (Expansions indicated by italics) 


\begin{abstract}
'After that the Romans chose Claudius Marcellus as consul, who was previously a companion of Scipio. He secretly went with a powerful force to that end of Hannibal's people where he himself was and killed many of that people and put [Hannibal] himself to flight. Then Marcellus had made it known to the Romans that Hannibal could be put to flight, although before they had questioned whether he could [ever] be put to flight with any army'. (Expansions indicated by italics)
\end{abstract}

OEO's treatment of Roman leadership during the Carthaginian invasions can be compared with ASC's account of the heroic conduct of West Saxon kings in leading the fight against the micel here. For example ASC 871 describes how "gefeaht Ellfred cyning wip alne pone here lytle werede æt Wiltune $\urcorner$ hine longe on dæg gefliemde" 'King Alfred fought against all the attacking-army at Wilton with a small troop and late in the day put them to flight' (emphasis added), while ASC 878 records that Alfred, again lytle werode, fought against the whole raiding-army, and put it to flight.

Recent events in Anglo-Saxon England again appear to inform the concluding lines of this section on the Punic Wars, in which the narrator of OEO departs from $\mathrm{OH}$ to provide his own personal reflection on the reversal of the fortunes of 'Rome': 115

$\mathrm{OH}$ IV.16.21: et tamen fortis in alterutrum desperatio in meliora profecit, nam in his omnibus desperando pugnarunt, pugnando uicerunt. ex quo euidenter ostenditur non tempora tunc fuisse tranquilliora otiis, sed homines miseriis fortiores.

115 It is tempting to connect OEO's account of the Lacedaemonian poet and king at the end of Bk I with the popular image of Alfred, who was said to have translated David's Psalms and is celebrated for his skills as both a poet and a king during a time of national crisis in the prose and verse prefaces to the Old English Boethius (see Irvine 2014a: 160-164). Compare OH I.21.7-8: 'The Lacedaemonians chose the Athenian poet, Tyrreus, as their war leader (Lat. ducem praelio). They were put to flight in three battles and made up for their lost army with a band of slaves whom they freed. But when, while they were still thinking of abandoning the fight from fear of its dangers, their leader, Tyrreus, who was both poet and general (Lat. poetae et ducis), composed a song and recited it at a meeting, they were enflamed once more and soon rushed into battle' (Zangemeister 1889: 76; Fear 2010: 71); OEO I.12: Ac gecuron him anne scop to cyninge of Atheniensem 7 eft mid firde foran wip pa Messene. Pa hi him nealæhtan, pa getweode hie hwæðer hie wið him mæhten. Se heora cyning ongan ða singan 7 giddian 7 mid bæm scopleoðe heora mod swiðe getrymede, to pon pæt hie cwædon pæt hie Mesiana folce wiðstondan mehten 'But they chose for themselves a poet as king from among the Athenians and afterwards went with an army against the Messenians. When they came near them, then they doubted whether they might be able to prevail against them. Then their king began to sing and to play and so greatly encouraged them with that poetic song, that they said that they might be able to withstand against the people of Messenii' (Bately 1980a: 35, 1. 12-17). Where $\mathrm{OH}$ gives the poet's name as Tyrreus, OEO leaves him nameless, but refers to him twice as cyning 'king' against the Latin dux 'war leader'. 


\begin{abstract}
'Nevertheless, a courage born of despair in each of these fields turned things out for the better. For in all these places they fought from despair, and from their fighting emerged victorious, by which we can clearly see that the times then were not any calmer from their being at leisure, but rather that men were braver in their misfortunes'. (Fear 2010: 188)
\end{abstract}

OEO IV.9: ac hie oft gebidon on lytlum stapole 7 on unwenlicum, pæt hie pa æt nihstan hæfdon ealra para anwald be ær neh heora hæfdon. (Bately 1980a: 103, 1. 5-7).

'But they stood on a small and hopeless foundation, so that, at last, they held sway over all those who, before, nearly had it over them'. (Emphasis added)

As Simeon Potter (1953: 423) has suggested, the author of OEO might well have had in mind the dark days of the 870 s when referring here to the hopelessness of former times and the precariousness of the Romans' situation. But the second half of this statement suggests that the author of $O E O$ is reflecting on the difficulties of the past from a position of relative safety and indeed power. It is difficult to see how someone writing from a West Saxon perspective could sustain such a view in the 890s, when the wars with the Danes were at their peak, both at land and sea (cf. ASC 894 [=893], 895 [=894], 897 [=896]) and the survival of Wessex, and indeed the angelcynn as a people, was far from certain. The statement in Alfred's obit (ASC 901 [=899]) that he was king ofer eall Ongelcyn butan ðæm dæle pe under Dena onwalde wæs 'over all the angelcynn except for that part that was under the control of the Danes' points as much to the limits of West Saxon anwald as to Alfred's remarkable achievements as king.

I would argue that authorial observations such as the one quoted above, on a beleaguered people's remarkable reversal of fortune, combined with the added emphasis on translatio imperii and the rise (rather than the fall) of Rome, suggest that $O E O$ might have been, if anything, more relevant to the political situation of early tenth-century Wessex than to the latter part of Alfred's reign. Like its main source, the $O E O$ views the events of history in the aftermath of a crisis which had threatened to overwhelm Christian civilisation. It was not until the reigns of Edward and Æthelstan, following the break-up of the Carolingian Empire, that West Saxon kings could claim with any confidence that they now had anwald over all their would-be conquerors or that, like their Roman forebears, they held sway over the whole island of Britain.

\title{
12 Conclusion
}

Accepting the traditional dating of $O E O$ to Alfred's reign, Kretzschmar suggests that, together with Old English Bede and ASC, this work is a product of the 
"academic desire to have a complete (on medieval grounds) history, for its intrinsic values and not for any ulterior political motive” (1987: 143-144). Similarly, despite his argument for widening the dating range, Godden (2011b: 21) finds little evidence to suggest $O E O$ had any relevance to contemporary Anglo-Saxon politics, either in the Alfredian era or shortly thereafter. Instead he suggests that it was undertaken primarily as a scholarly, antiquarian exercise, to provide English readers with important facts about world history and geography. This article has argued, however, that the $O E O$ reflects the political aspirations of the West Saxon court in the late ninth and early tenth centuries. More specifically, it proposes that OEO was read and perhaps revised - through the insertion of the reports of Ohthere and Wulfstan - in the early tenth century to further the nascent cause of West Saxon imperialism. The identification of the scribe of the Lauderdale Orosius with the ASC entries for 891 (second part)-920 and the Junius Psalter hints at the activity of the royal scriptorium at Winchester in the 920s and 930s (Parkes 1976: 154, n. 1). Edward himself may, as William of Malmesbury remarks, have been litterarum scientia multum patre inferior 'much inferior to his father in booklearning' (GRA, II.125; Mynors et al. 1998, I: 197), but in his military achievements as a conqueror of other kings and peoples, he far outshone Alfred, ${ }^{116}$ and the copying and circulation of books such as OEO, the ASC and the Junius Psalter during his reign may have served to cement his reputation as an English monarch of unprecedented power. Better attested is Æthelstan's reputation as both an acquirer and distributor of books, qualities which played a key role in sustaining his image as patron of scholars and emperor (Wood 1983; Keynes 1985; Dumville 1992b; Pratt 2014: 334-342). As we have seen, the ASC entries for this period present the establishment of West Saxon anwald over the various peoples and kings of Britain as the completion of conquest and conversion of the island begun centuries earlier by Roman emperors and bishops. Mechthild Gretsch has argued that, following the integration of Anglian and Saxon ethnicities in the new 'Kingdom of the Anglo-Saxons' under Edward, the mixture of Mercian and early West Saxon linguistic features in the interlinear Old English gloss to the Junius Psalter can be viewed as "a reflection, in a conscious or subconscious way, of an emerging political order" (2000: 122). Of course, the Psalms themselves legitimize the extension of royal power through the conquests of David: in the words of the Junius Psalter gloss to Psalm 17 (18).43, pu gesetes me in heafod ðeoda 'you set me as the

116 William continues: sed regni potestate incomparabiliter gloriosor 'but in his power and glory as a king there was no comparison' (GRA, II.125; Mynors et al. 1998, I: 197). See Gallagher (forthcoming) for the continuing presence of at least some of Alfred's scholars at the royal court after 899. See McGurk (1986) for evidence of Latin writing in the first decade of the tenth century. On vernacular writing post-Alfred more generally, see further Atherton (forthcoming). 
head of nations' (Brenner 1908: 20). ${ }^{117}$ Considered together with these works in the context of early tenth century West Saxon court culture, the Lauderdale Orosius our earliest witness to $O E O$ - helps to explain the emergence of this new political order in terms of the wider history of translatio imperii: Wessex stands at the end of a long line of great empires. In Orosian rhetoric, this transference of power from continent to island is to be understood as a manifestation of God's judgment on the conduct of its kings. OEO may also therefore have served a more practical, didactic purpose as a moral exemplum, complementing other West Saxon texts of this period associated with Alfred. ${ }^{118}$ Peter Van Nuffelen (2012: 53) has recently argued that, for Orosius, Rome is not an eternal city, but rather one temporarily spared by God due to its Christianity, which will continue to rule only for as long as its rulers uphold their Christian morality. In a passage puzzlingly inconsistent with his usual statements on the endurance of the Christian Empire, ${ }^{119}$ Orosius observes that Rome is now "tottering” from old age:

OH II.6.14: si potentissimae illae quondam Romanae reipublicae moles nunc magis inbecillitate propriae senectutis quam alienis concussae uiribus contremescunt.

'The once mighty foundations of the Roman state are now tottering not from the blows of foreign foes, but rather from the weakness of its own old age'. (Fear 2010: 85)

However, in a characteristically subtle refashioning of $\mathrm{OH}$ the English translator emphasizes that Rome nonetheless still continues to enjoy God's protection because of the Christianity of her rulers:

OEO II.4: $[A] c$ heo for hiere cristendome nugiet is gescild, ðæt ægper ge hio self ge hiere anweald is ma hreosende for ealddome ponne of æniges cyninges niede. ${ }^{120}$ (Bately 1980a: 44, 1. 14-16). (Expansion in italics)

'But she (Rome) for her Christian faith is protected even now, so that both herself and her empire are falling more because of old age than for the hostility of any king'. (Expansion in italics)

117 Cf. Pss. 71(72).8-11, 88(89).25.

118 See Leneghan (2010).

119 Fear (2010: 85, n. 72): “This statement contrasts with Orosius's normal optimism about the future of Christian Rome and appears to be a reversion to pagan theories of cyclical history".

120 Bately (1980a: 236) comments that OEO places more emphasis on parallels between Rome and Babylon, while Harris (2001: 500) interprets this passage as indicating that, while for Orosius "the Empire had not fallen; instead it had simply been reprimanded by God", for the author of $O E O$, "Rome was falling". But elsewhere, as we have seen, $O E O$ repeatedly emphasizes the endurance of Rome. 
The renovatio of the imperium romanum may have faltered at the end of the ninth century with the collapse of the Carolingian dynasty and its empire, but the conquests of West Saxon kings in the early tenth century appear to have encouraged some contemporaries to believe, however briefly, that Wessex was to inherit the Roman imperial mantle from Francia. As well as acting as a charter for this translatio imperii from continent to island, OEO might also have served to remind West Saxon kings that, if they are to continue to enjoy God's protection as rulers of a heafodrice 'empire', they must, like their Roman and Carolingian predecessors, always strive to uphold hiere cristendome 'their Christian faith'. ${ }^{121}$

\section{Works Cited}

Airlie, Stuart. 2006. “'Sad Stories of the Death of Kings': Narrative Patterns and Structures of Authority in Regino of Prum's Chronicon”. In: Elizabeth M. Tyler and Ross Balzaretti (eds.). Narrative and History in the Early Medieval West. Studies in the Early Middle Ages 16. Turnhout: Brepols. 105-131.

Allen, Michael I. 2003. “Universal History 300-1000: Origins and Western Development”. In: Deborah M. Deliyannis (ed.). Historiography in the Middle Ages. Leiden: Brill. 17-42.

Anlezark, Daniel. 2002. "Sceaf, Japheth and the Origins of the Anglo-Saxons". ASE 31: 13-46. Anlezark, Daniel. 2013. “The Anglo-Saxon World View”. In: Malcolm Godden and Michael Lapidge (eds.). The Cambridge Companion to Old English Literature. 2nd ed. Cambridge: Cambridge University Press. 66-81.

Appleton, Helen. 2013. “Anglo-Saxon Landscapes: The Construction of the Environment in Old English and Related Texts". Unpubl. PhD dissertation, University of Sydney.

Atherton, Mark. forthcoming. The Making of England: A New History of the Anglo-Saxon World. London: I. B. Tauris.

Bately, Janet M. 1966. “The Old English Orosius: The Question of Dictation”. Anglia 84: 255-304.

Bately, Janet M. 1970. “King Alfred and the Old English Translation of Orosius”. Anglia 88: 433-460.

Bately, Janet M. 1979. "World History in the Anglo-Saxon Chronicle: Its Sources and its Separateness from the Old English Orosius". Anglo-Saxon England 8: 177-194.

Bately, Janet M. (ed.). 1980a. The Old English Orosius. EETS SS 6. London: Oxford University Press.

Bately, Janet M. 1980b. The Literary Prose of Alfred's Reign: Translation or Transformation?. London: University of London, King's College.

Bately, Janet M. 1985. "The Compilation of the Anglo-Saxon Chronicle Once More". Leeds Studies in English 16: 7-26.

121 I would like to thank Mark Atherton, Jim Earl, Malcolm Godden, Andy Orchard and the anonymous reviewers of Anglia for many helpful comments on earlier versions of this article. Any errors are, of course, my own. 
Bately, Janet M. (ed.). 1986. The Anglo-Saxon Chronicle: A Collaborative Edition. Volume 3: MS A. Cambridge: Brewer.

Bately, Janet M. 1988. “Old English Prose before and during the Reign of King Alfred”. AngloSaxon England 17: 93-138.

Bately, Janet M. 2003. “The Alfredian Canon Revisited: One Hundred Years One”. In: Reuter (ed.). 107-120.

Bately, Janet M. and Anton Englert (eds.). 2007. Ohthere's Voyages: A 9th-Century Account of Voyages along the Coasts of Norway and Denmark and its Cultural Context. Maritime Culture of the North 1. Roskilde: Viking Ship Museum.

Bately, Janet M. 2009. "Did King Alfred Actually Translate Anything? The Integrity of the Alfredian Canon Revisited". Medium AEvum 76: 1-23.

Bately, Janet M. 2014. “The Old English Orosius”. In: Discenza and Szarmach (eds). 313-343.

Bettenson, Henry (trans.). 1972. Saint Augustine: Concerning the City of God against the Pagans. London: Penguin.

Bischoff, Bernhard. 2014. Katalog der festländischen Handschriften des neunten Jahrhunderts (mit Ausnahme der wisigotischen). Volume 3: Padua-Zwickau. Wiesbaden: Harrassowitz.

Bosworth, Joseph (trans.). 1859. King Alfred's Anglo-Saxon Version of the Compendious History of the World by Orosius. London: Longman, Brown, Green \& Longmans.

Bosworth-Toller = Bosworth, Joseph and T. Northcote Toller (eds.). 1882-1898. An Anglo-Saxon Dictionary. Oxford: Clarendon; Toller, T. Northcote (ed.). 1908-1921. Supplement to An Anglo-Saxon Dictionary Based on the Manuscript Collections of the Late Joseph Bosworth. Oxford: Clarendon.

Brenner, Eduard (ed.). 1908. Die altenglische Junius-Psalter: Die Interlinear-Glosse der Handschrift Junius 27 der Bodleiana zu Oxford. Heidelberg: Winter.

Brooks, Nicholas. 2010. "Why is the Anglo-Saxon Chronicle about Kings?". Anglo-Saxon England 39: 43-70.

Campbell, Alistair (ed. and trans.). 1962. The Chronicle of Athelweard. London: Nelson \& Sons.

Coz, Yann. 2010. “The Image of Roman History in Anglo-Saxon England”. In: Rollason, Leyser and Williams (eds.). 545-558.

Curtius, Ernst Robert. 1953. European Literature and the Latin Middle Ages. Trans. Willard R. Trask. New Jersey: Princeton University Press.

Davidson, Michael R. 2001. “The (non)Submission of the Northern Kings in 920". In: Higham and Hill (eds.). 200-211.

Discenza, Nicole Guenther. 2006. “A Map of the Universe: Geography and Cosmology in the Program of Alfred the Great”. In: Catherine E. Karkov and Nicholas Howe (eds.). Conversion and Colonization in Anglo-Saxon England. ISAS Essays in Anglo-Saxon Studies 2. Arizona: Arizona Center for Medieval and Renaissance Studies. 83-108.

Discenza, Nicole Guenther and Paul E. Szarmach (eds.). 2014. A Companion to Alfred the Great. Brill's Companions to the Christian Tradition 58. Leiden: Brill.

$D O E=$ Cameron, Angus, Ashley Crandell Amos, Antonette diPaolo Healey et al. (eds.). 2007. Dictionary of Old English: A to $G$ online. Toronto: Dictionary of Old English Project: <http://www.doe.utoronto.ca> [accessed 3rd March 2015].

Dumville, David N. 1986. "The West Saxon Genealogical Regnal List: Manuscripts and Texts”. Anglia 104: 1-32.

Dumville, David N. 1992a. "The Anglo-Saxon Chronicle and the Origins of English Square Minuscule Script”. In: Dumville. Wessex and England from Alfred to Edgar: Six Essays on Political, Cultural and Ecclesiastical Revival. Woodbridge: Brewer. 55-99. 
Dumville, David N. 1992b. "Between Alfred the Great and Edgar the Peaceable: Æthelstan, First King of England”. In: Dumville. Wessex and England. 141-172.

Dumville, David N. 1997. "The Terminology of Overkingship in Early Anglo-Saxon England". In: John Hines (ed.). The Anglo-Saxons from the Migration Period to the Eighth Century: An Ethnographic Perspective. Woodbridge: Boydell. 345-374.

Englert, Anton and Athena Trakadas (eds.). 2009. Wulfstan's Voyage: The Baltic Sea Region in the Early Viking Age as Seen from Shipboard. Maritime Culture of the North 2. Roskilde: Viking Ship Museum.

Enright, Michael J. 1979. "Charles the Bald and Aethelwulf of Wessex: The Alliance of 856 and Strategies of Royal Succession". Journal of Medieval History 5: 291-302.

Fanning, Steven. 1991. "Bede, Imperium, and the Bretwaldas”. Speculum 66: 1-26.

Fear, Andy T. (ed. and trans.). 2010. Orosius: Seven Books of History against the Pagans. Liverpool: Liverpool University Press.

Fichtenau, Heinrich. 1968. The Carolingian Empire. Trans. Peter Munz. Oxford: Blackwell. 47-78.

Foot, Sarah. 1996. "The Making of Angelcynn: English Identity before the Norman Conquest". Transactions of the Royal Historical Society, 6th ser., 6: 25-49. Repr. in: Roy M. Liuzza (ed.). Old English Literature: Critical Essays. New Haven, CT: Yale University Press. 51-78.

Foot, Sarah. 2005. "Finding the Meaning of Form: Narrative in Annals in Chronicles". In: Nancy F. Partner (ed.). Writing Medieval History. London: Hodder Arnold. 88-108.

Foot, Sarah. 2008. "Where English Becomes British: Rethinking Contexts for Brunanburh". In: Julia Barrow and Andrew Wareham (eds.). Myth, Rulership, Church and Charters: Essays in Honour of Nicholas Brooks. Aldershot: Ashgate. 127-144.

Foot, Sarah. 2010. “Dynastic Strategies: The West Saxon Royal Family in Europe”. In: Rollason, Leyser and Williams (eds.). 237-253.

Foot, Sarah. 2011. Athelstan: The First King of England. New Haven, CT: Yale University Press.

Frantzen, Allen J. 2003. "The Form and Function of the Preface in the Poetry and Prose of Alfred's Reign”. In: Reuter (ed.). 121-136.

Gallagher, Robert. forthcoming. "Latin Literary Culture in the Age of Alfred the Great and Edward the Elder”. Unpubl. PhD dissertation, University of Cambridge.

Glorie, Francis (ed.). 1964. S. Hieronymi Presbyteri: Commentariorum in Danielem Libri III. CCSL 75A. Turnhout: Brepols.

Gneuss, Helmut and Michael Lapidge. 2014. Anglo-Saxon Manuscripts: A Bibliographical Handlist of Manuscripts and Manuscript Fragments Written or Owned in England up to 1100. Toronto: University of Toronto Press.

Godden, Malcolm R. 2002. "The Anglo-Saxons and the Goths: Rewriting the Sack of Rome”. Anglo-Saxon England 31: 47-68.

Godden, Malcolm R. 2007. “Did King Alfred Write Anything?”. Medium Aevum 76: 1-23.

Godden, Malcolm R. 2009. "The Alfredian Project and its Aftermath: Rethinking the Literary History of the Ninth and Tenth Centuries". Proceedings of the British Academy 162: 93-122.

Godden, Malcolm and Susan Irvine (eds.). 2009. The Old English Boethius: An Edition of the Old English Versions of Boethius's De Consolatione Philosophiae. 2 vols. Oxford: Oxford University Press.

Godden, Malcolm R. 2011a. "The Old English Orosius and its Sources”. Anglia 129: 297-320.

Godden, Malcolm R. 2011b. "The Old English Orosius and its Context: Who Wrote it, for Whom, and Why?". Quaestio Insularis: Selected Proceedings of the Cambridge Colloquium in Anglo-Saxon, Norse and Celtic 12: 1-30. 
Godden, Malcolm R. 2011c. "Prologues and Epilogues in the Old English Pastoral Care, and their Carolingian Models". Journal of English and Germanic Philology 110: 441-433.

Godden, Malcolm R. 2013. “Alfredian Prose: Myth and Reality”. Filologia Germanica 5: 131-158.

Goez, Werner. 1958. Translatio Imperii: Ein Beitrag zur Geschichte des Geschichtsdenkens und der politischen Theorien im Mittelalter und in der frühen Neuzeit. Tübingen: Mohr.

Gretsch, Mechthild. 2000. "The Junius Psalter Gloss: Its Historical and Cultural Context”. AngloSaxon England 29: 85-121.

Haefele, Hans F. (ed.). 1959. Notker der Stammler: Taten Kaiser Karls des Grossen. MGH Script. rer. Germ. n.s. 12. Berlin: Weidmann.

Harris, Stephen J. 2001. "The Alfredian World History and Anglo-Saxon Identity”. JEGP 100: 482-510. Repr. in: Stephen J. Harris. 2003. Race and Ethnicity in Anglo-Saxon Literature. New York: Taylor \& Francis. 83-106.

Higham, N. J. 1995. An English Empire: Bede and the Early Anglo-Saxon Kings. Manchester: University of Manchester Press.

Higham N. J. and David Hill (eds.). 2001. Edward the Elder, 899-924. Abingdon: Routledge. Hillgarth, Jocelyn N. 1992. "The Historiae of Orosius in the Early Middle Ages”. In: Louis Holtz, Jean-Claude Fredouille and M. H. Jullien (eds.). De Tertullien aux Mozarabes II: Antiquité tardive et Christianisme ancien (Vle-Ixe siècles). Mélanges offerts à Jacques Fontaine. Paris: Institut d'études augustiniennes. 161-170.

Hodges Richard and David Whitehouse. 1983. Mohammed, Charlemagne and the Origins of Europe: Archaeology and the Pirenne Thesis. London: Duckworth.

Hodges, Richard. 2000. Towns and Trade in the Age of Charlemagne. London: Duckworth. Holder-Egger, Oswald (ed.). 1911. Einhardi Vita Karoli Magni. MGH Script. rer. Germ. 25. Hannover: Hahn.

Howe, Nicholas. 1989. Migration and Mythmaking in Anglo-Saxon England. Notre Dame: University of Notre Dame Press.

Howe, Nicholas. 2001. "Rome: Capital of Anglo-Saxon England”. Journal of Medieval and Early Modern Studies 34: 147-172. Repr. in: Nicholas Howe. 2008. Writing the Map of AngloSaxon England: Essays in Cultural Geography. New Haven, CT: Yale University Press. 101-124.

Hurley, Mary Kate. 2013. “Alfredian Temporalities: Time and Translation in the Old English Orosius". Journal of English and Germanic Philology 112: 405-432.

Innes, Matthew. 1997. "The Classical Tradition in the Carolingian Renaissance: Ninth-Century Encounters with Suetonius”. International Journal of the Classical Tradition 3: 265-282.

Irvine, Susan. 2001. “Religious Context: Pre-Benedictine Reform Period”. In: Philip Pulsiano and Elaine Treharne (eds.). A Companion to Anglo-Saxon Literature. Malden, MA: Blackwell. 135-150.

Irvine, Susan. 2003a. "The Anglo-Saxon Chronicle and the Idea of Rome in Alfredian Literature". In: Reuter (ed.). 63-78.

Irvine, Susan. 2003b. "Wrestling with Hercules: King Alfred and the Classical Past”. In: Catherine Cubitt (ed.). Court Culture in the Early Middle Ages: The Proceedings of The First Alcuin Conference. Turnhout: Brepols. 171-188.

Irvine, Susan. 2014a. “The Alfredian Prefaces and Epilogues”. In: Discenza and Szarmach (eds.). 143-170.

Irvine, Susan. 2014b. “The Anglo-Saxon Chronicle”. In: Discenza and Szarmach (eds.). 344-367. John, Eric. 1966. “Orbis Britanniae and the Anglo-Saxon Kings”. In: Eric John. Orbis Britanniae and Other Studies. Leicester: Leicester University Press. 1-63. 
Jorgensen, Alice (ed.). 2010. Reading the Anglo-Saxon Chronicle. Studies in the Early Middle Ages 23. Turnhout: Brepols.

Karkov, Catherine E. 2004. The Ruler Portraits of Anglo-Saxon England. Anglo-Saxon Studies 2. Woodbridge: Boydell.

Ker, Neil R. 1957. Catalogue of Manuscripts Containing Anglo-Saxon. Oxford: Clarendon.

Keynes, Simon. 1985. “King Æthelstan’s Books”. In: Michael Lapidge and Helmut Gneuss (eds.). Learning and Literature in Anglo-Saxon England. Cambridge: Cambridge University Press. 143-201.

Keynes, Simon and Michael Lapidge (eds. and trans.). 1983. Alfred the Great: Asser's 'Life of King Alfred' and Other Contemporary Sources. Harmondsworth: Penguin.

Keynes, Simon. 1997. “Anglo-Saxon Entries in the 'Liber Vitae' of Brescia”. In: Jane Roberts and Janet L. Nelson with Malcolm Godden (eds.). Alfred the Wise: Studies in Honour of Janet Bately on the Occasion of her Sixty-Fifth Birthday. Cambridge: Boydell \& Brewer. 99-120.

Keynes, Simon. 2001. “Edward, King of the Anglo-Saxons”. In: Higham and Hill (eds.). 40-66.

Keynes, Simon. 2008. “Edgar, rex admirabilis”. In: Donald Scragg (ed.). Edgar: King of the English, 959-975. Woodbridge: Boydell. 3-59.

Keynes, Simon. 2014. "Alfred the Great and the Kingdom of the Anglo-Saxons”. In: Discenza and Szarmach (eds.). 13-46.

Khalaf, Omar. 2013. "A Study on the Translator's Omissions and Instances of Adaptation in The Old English Orosius: The Case of Alexander the Great”. Filologia Germanica 5: 195-222.

Kretzschmar Jr., William A. 1987. "Adaptation and anweald in the Old English Orosius". AngloSaxon England 16: 127-145.

Ladner, Gerhart B. 1983. Images and Ideas in the Middle Ages: Selected Studies in History and Art II. Rome: Edizioni de Storia e Litteratura.

Lapidge, Michael (ed. and trans.). 1981. "Some Latin Poems as Evidence for the Reign of Athelstan”. Anglo-Saxon England 9: 61-98.

Lapidge, Michael. 2003. “Asser’s Reading”. In: Reuter (ed.). 27-48.

Lapidge, Michael. 2006. The Anglo-Saxon Library. Oxford: Oxford University Press.

Lavelle, Ryan. 2010. Alfred's Wars: Sources and Interpretations of Anglo-Saxon Warfare in the Viking Age. Woodbridge: Boydell \& Brewer.

Leneghan, Francis. 2010. "Royal Wisdom and the Alfredian Context of Cynewulf and Cyneheard". Anglo-Saxon England 39: 71-104.

Levison, Wilhelm. 1946. England and the Continent in the Eighth Century. The Ford Lectures, 1943. Oxford: Clarendon.

Leyser, Karl. 1982. Medieval Germany and its Neighbours, 900-1250. London: Hambledon.

Liebermann, Felix (ed.). 1903. Die Gesetze der Angelsachsen. Volume 1: Text und Übersetzung. Halle: Niemeyer.

Liggins, Elizabeth. 1970. “The Authorship of the Old English Orosius”. Anglia 88: 289-322.

Loomis, Laura Hibbard. 1950. "The Holy Relics of Charlemagne and King Athelstan: The Lances of Longinus and St. Mauricius”. Speculum 25: 437-456.

Loyn, Henry R. 1955. “The Imperial Style of the Tenth Century Anglo-Saxon Kings”. History 40: 111-115.

MacAirt, Seán and Gearóid Mac Miocaill (eds. and trans.). 1983. The Annals of Ulster (to AD 1131). Part I: Text and Translation. Dublin: Dublin Institute for Advanced Studies.

MacLean, Simon. 2003. Kingship and Politics in the Late Ninth Century: Charles the Fat and the End of the Carolingian Empire. Cambridge: Cambridge University Press. 
MacLean, Simon (ed. and trans.). 2009. History and Politics in Late Carolingian and Ottonian

Europe: The 'Chronicle' of Regino of Prüm and Adalbert of Magdeberg. Manchester:

Manchester University Press.

Maddicott, J. R. 1989. "Trade, Industry and the Wealth of King Alfred". Past and Present 123: 3-51.

Magoun Jr., Francis P. 1951. “King Aethelwulf's Biblical Ancestors”. Modern Language Review 46: 249-250.

Mayr-Harting, Henry. 2001. “The Early Middle Ages”. In: Richard Harries and Henry Mayr-Harting (eds.). Christianity: Two Thousand Years. Oxford: Oxford University Press. 44-64.

McCormick, Michael. 2001. Origins of the European Economy: Communications and Commerce, $A D$ 300-900. Cambridge: Cambridge University Press.

McGurk, Patrick. 1986. "The Metrical Calendar of Hampson: A New Edition”. Analecta Bollandiana 104: 79-125.

McKitterick, Rosamund. 1983. The Frankish Kingdoms under the Carolingians, 751-987. London: Longman.

McKitterick, Rosamund. 2008. Charlemagne: The Formation of a European Identity. Cambridge: Cambridge University Press.

Michelet, Fabienne L. 2006. Creation, Migration and Conquest: Imaginary Geography and Sense of Space in Old English Literature. Oxford: Oxford University Press.

Molyneaux, George. 2011. "Why were Some Tenth-Century English Kings Presented as Rulers of Britain?". Transactions of the Royal Historical Society 21: 59-91.

Molyneaux, George. 2014. "Did the English Really Think they Were God's Elect in the Anglo-Saxon Period?". Journal of Ecclesiastical History 65: 721-737.

Molyneaux, George. 2015. The Formation of the English Kingdom in the Tenth Century. Oxford: Oxford University Press.

Mortensen, Lars B. 1999-2000. "The Diffusion of Roman Histories in the Middle Ages: A List of Orosius, Eutropius, Paulus Diaconus and Landolfus Sagax Manuscripts”. Filologia Mediolatina 6-7: 100-209.

Murray, Alexander C. 1981. "Beowulf, the Danish Invasions, and Royal Genealogy”. In: Colin Chase (ed.). The Dating of 'Beowulf'. Toronto: University of Toronto Press. 101-111.

Mynors, Roger A. B., Rodney M. Thomson and Michael Winterbottom (eds.). 1998. William of Malmesbury: Gesta Regum Anglorum. Volume 1. Oxford: Clarendon.

Nelson, Janet L. 1967. “The Problem of King Alfred's Royal Anointing”. The Journal of Ecclesiastical History 18: 145-163.

Nelson, Janet L. 1977. “Inauguration Rituals”. In: Peter H. Sawyer and lan N. Wood (eds.). Early Medieval Kingship. Leeds: University of Leeds, School of History. 50-71.

Nelson, Janet L. 1986. "Wealth and Wisdom: The Politics of Alfred the Great”. In: Joel T. Rosenthal (ed.). Kings and Kingship. Acta 11. Binghamton, NY: Center for Medieval and Early Renaissance Studies, SUNY. 31-52.

Nelson, Janet L. 1988. “Kingship and Empire”. In: J. H. Burns (ed.). The Cambridge History of Medieval Political Thought, c.350-c.1450. Cambridge: Cambridge University Press. 211-251.

Nelson, Janet L. (ed. and trans.). 1991. The Annals of St. Bertin. Manchester: Manchester University Press.

Nelson, Janet L. 1997. "The Franks and the English in the Ninth Century Reconsidered”. In: Paul E. Szarmach and Joel T. Rosenthal (eds.). The Preservation and Transmission of AngloSaxon Culture: Selected Papers from the 1991 Meeting of the International Society of AngloSaxonists. Kalamazoo: Medieval Institute Publications. 141-158. 
Nelson, Janet L. 2003. “Alfred’s Carolingian Contemporaries”. In: Reuter (ed.). 293-310.

Ortenberg, Veronica. 2010. “The King from Overseas: Why Did Ætthelstan Matter in Tenth-Century Continental Affairs?”. In: Rollason, Leyser and Williams (eds.). 211-236.

Ortenberg, Veronica. 2014. "Roman Highlights and their English Afterlife". In: Francesca Tinti (ed.). England and Rome in the Early Middle Ages: Pilgrimage, Art and Politics. Studies in the Early Middle Ages 40. Turnhout: Brepols. 179-216.

Parkes, Malcolm. 1976. "The Paleography of the Parker Manuscript of the Chronicle, Laws and Sedulius, and Historiography at Winchester in the Late Ninth and Tenth Centuries". In: Malcolm Parkes (ed.). Scribes, Scripts and Readers: Studies in the Communication, Presentation, and Dissemination of Mediaeval Texts. London: Hambledon Continuum. 143-169.

Pengelly, Oliver. 2010. "Rome in Ninth-Century Anglo-Saxon England”. Unpubl. PhD dissertation, University of Oxford.

Pezzarossa, Lucrezia. 2013. "Reading Orosius in the Viking Age: An Influential Yet Problematic Model”. Filologia Germanica 5: 223-240.

Pirenne, Henri. 1925. Medieval Cities: Their Origins and the Revival of Trade. New York: Princeton University Press.

Pirenne, Henri. 1939. Mohammed and Charlemagne. London: Allen \& Unwin.

Potter, Simeon. 1953. “Commentary on King Alfred's Orosius”. Anglia 71: 385-437.

Pratt, David. 2007a. The Political Thought of King Alfred the Great. Cambridge: Cambridge University Press.

Pratt, David. 2007b. "Problems of Authorship and Audience in the Writings of King Alfred the Great". In: Wormald and Nelson (eds.). 162-191.

Pratt, David. 2014. "Kings and Books". Anglo-Saxon England 43: 297-377.

Reuter, Timothy (ed.). 2003. Alfred the Great: Papers from the Eleventh-Centenary Conferences. Aldershot: Ashgate.

Reuter, Timothy. 2006. “The End of Carolingian Military Expansion”. In: Timothy Reuter and Janet Nelson (eds.). Medieval Polities and Modern Mentalities. Cambridge: Cambridge University Press. 251-267.

Rollason, David, Conrad Leyser and Hannah Williams (eds.). 2010. England and the Continent in the Tenth Century: Studies in Honour of Wilhelm Levison (1876-1947). Turnhout: Brepols.

Rosier, James Louis (ed.). 1962. The Vitellius Psalter: Edited from British Museum MS. Cotton Vitellius Exviii. Cornell Studies in English 42. Ithaca, NY: Cornell University Press.

Russell, Paul. 2011. “Revisiting the 'Welsh Dictator' of the Old English Orosius”. Quaestio Insularis: Selected Proceedings of the Cambridge Colloquium in Anglo-Saxon, Norse and Celtic 12: 31-62.

Sawyer, Peter H. 1998. From Roman Britain to Norman England. 2nd ed. London: Routledge.

Sawyer, Peter H. et al. (eds.). The Electronic Sawyer: Online Catalogue of Anglo-Saxon Charters. <http://www.esawyer.org.uk/charter/392.html> [accessed 2nd March 2015].

Scharer, Anton. 2010. “The Anglo-Saxon Chronicle and Continental Annal-Writing”. In: Jorgensen (ed.). 161-167.

Shippey, Thomas A. 1979. "Wealth and Wisdom in King Alfred's Preface to the Pastoral Care". English Historical Review 94: 346-355.

Snook, Ben. 2015. The Anglo-Saxon Chancery: The History, Language and Production of AngloSaxon Charters from Alfred to Edgar. Woodbridge: Boydell.

Stafford, Pauline. 1980. “Charles the Bald, Judith and England”. In: Martin T. Gibson, Janet L. Nelson and David Ganz (eds.). Charles the Bald: Court and Kingdom. British Archaeological Reports, International Series 101. Oxford: BAR. 139-153. 
Stafford, Pauline. 1989. Unification and Conquest: A Political and Social History of England in the Tenth and Eleventh Centuries. London: Hodder Arnold.

Stenton, Frank M. 1970. Preparatory to Anglo-Saxon England: Being the Collected Papers of Frank Merry Stenton. Ed. Doris Mary Stenton. Oxford: Oxford University Press.

Stenton, Frank M. 1971. Anglo-Saxon England. 3rd ed. Oxford: Oxford University Press.

Stevenson, William H. 1911. "A Latin Poem Addressed to King Athelstan”. English Historical Review 16: 482-487.

Stevenson, William H. (ed.). 1959. Asser's Life of King Alfred Together with the Annals of St Neots Erroneously Attributed to Asser: New Imprint with Article on Recent Work by Dorothy Whitelock. Oxford: Clarendon.

Stodnick, Jacqueline. 2006. "The Interests of Compounding: Angelcynn to Engla land in The Anglo-Saxon Chronicle". In: Hugh Magennis and Jonathan Wilcox (eds.). The Power of Words: Anglo-Saxon Studies Presented to Donald Scragg on his Seventieth Birthday. Morgantown, WV: West Virginia University Press. 337-367.

Story, Joanna. 2003. Carolingian Connections: Anglo-Saxon England and Carolingian Francia, c. 750-850. Aldershot: Ashgate.

Sweet, Henry (ed. and trans.). 1871-1872. King Alfred's West-Saxon Version of Gregory's Pastoral Care. 2 vols. EETS SS 45, 50. London: Trübner \& Co.

Thomas, Hans. 1997. “Translatio Imperii”. In: Robert Auty et al. (eds). Lexikon des Mittelalters. Volume 8. Munich: Lexma. 944-946.

Thorpe, Lewis (trans.). 1969. Einhard and Notker the Stammerer: Two Lives of Charlemagne. Harmondsworth: Penguin.

Tristram, Hildegard. 1982. “Ohthere, Wulfstan und der Aethicus Ister”. Zeitschrift für deutsches Altertum und deutsche Literatur 111: 153-168.

Tyler, Elizabeth. 2013. "Trojans in Anglo-Saxon England: Precedent without Descent”. Review of English Studies 64: 1-20.

Tyler, Elizabeth. forthcoming. "Making History Universal: The Old English Orosius and the AngloSaxon Chronicle in London, British Library, Cotton Tiberius B. i". In: Michele Campopiano (ed.). Finding your Place in History and Politics: The Life of Universal Chronicles in the High Middle Ages. Woodbridge/York: Boydell \& Brewer.

Ullmann, Walter. 1969. The Carolingian Renaissance and the Idea of Kingship: The Birkbeck Lectures, 1968-9. London: Methuen.

Valtonen, Irmeli. 2008. The North in the Old English Orosius: A Geographical Narrative in Context. Helsinki: Société Néophilologique de Helsinki.

Van Nuffelen, Peter. 2012. Orosius and the Rhetoric of History. Oxford: Oxford University Press.

Verger, Jacques. 1997. “Translatio studii”. In: Robert Auty et al. (eds). Lexikon des Mittelalters. Volume 8. Munich: Lexma. 946-947.

Verhulst, Adriaan. 1999. The Rise of Cities in North-West Europe. Cambridge: Cambridge University Press.

Wallace-Hadrill, John M. 1975. "The Franks and the English in the Ninth Century: Some Common Historical Interests”. In: Wallace-Hadrill. Early Medieval History. Oxford: Blackwell. 201-216.

Waite, Gregory. 2000. Annotated Bibliographies of Old and Middle English Literature VI: Old English Prose Translations of King Alfred's Reign. Cambridge: Boydell \& Brewer.

Whitelock, Dorothy. 1966. “The Prose of Alfred's Reign”. In: E. G. Stanley (ed.). Continuations and Beginnings. London: Nelson. 66-103.

Whitelock, Dorothy (ed. and trans.). 1979. English Historical Documents. Volume I: 500-1042. 2nd ed. London: Routledge. 
Wood, Michael. 1983. “The Making of King Aethelstan's Empire: An English Charlemagne?”. In: Patrick Wormald, with Donald Bullough and Roger Collins (eds.). Ideal and Reality in AngloSaxon and Frankish Society. Oxford: Blackwell. 250-272.

Wood, Michael. 2007. “'Stand Strong against the Monsters': Kingship and Learning in the Empire of King Æthelstan”. In: Wormald and Nelson (eds.). 192-217.

Wood, Michael. 2010. “A Carolingian Scholar in the Court of King Æthelstan”. In: Rollason, Leyser and Williams (eds.). 135-162.

Wormald, Patrick. 1983. "Bede, Bretwaldas and the Origins of the Gens Anglorum”. In: Patrick Wormald (ed.). Idea and Reality in Frankish and Anglo-Saxon Society: Studies Presented to J. M. Wallace-Hadrill. Oxford: Blackwell. 99-129. Repr. in: Patrick Wormald. 2006. The Times of Bede 625-865: Studies in Early English Christian Society and its Historian. Oxford: Blackwell. 106-134.

Wormald, Patrick. 1994. "Engla lond: The Making of an Allegiance". Journal of Historical Sociology $7: 1-24$.

Wormald, Patrick and Janet Nelson (eds.). 2007. Lay Intellectuals in the Carolingian World. Cambridge: Cambridge University Press.

Yardely, John C. (trans.). 1994. Justin: Epitome of the Philippic History of Pompeius Trogus. American Philological Association, Classical Resources Series 3. Atlanta, GA: Scholars Press.

Yorke, Barbara. 2001. “Edward as Atheling”. In: Higham and Hill (eds.). 25-39.

Yorke, Barbara. 2010. “The Representation of Early West Saxon History in the Anglo-Saxon Chronicle”. In: Jorgensen (ed.). 141-160.

Zangemeister, Karl F. W. (ed.). 1889. Pauli Orosii Historiarum adversum paganos libri VII. CSEL 5. Leipzig: Teubner. 